いしはて、可的不を仮コ脱

亡従同こ加性会・提法はへ動!

しつ時のし注㹂に的次ン研卜

して、仮、そ言張す機のや究ン

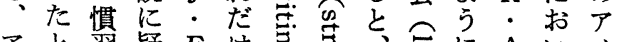

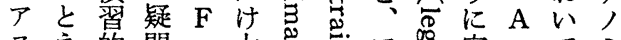

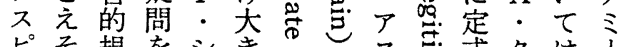

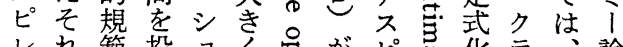

レれ範投 $コ$ 要がピ劳化ラ、論

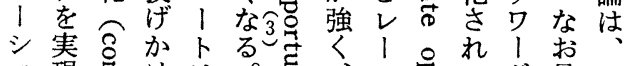

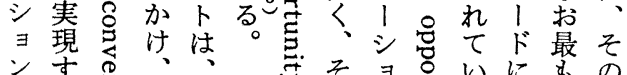

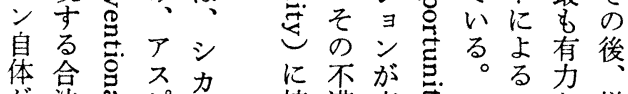

が法さピゴ 接満高导离な様

非的 $レ$ 近のい仮名

合機导に打守ゆたに説の

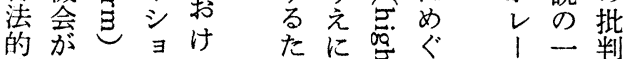

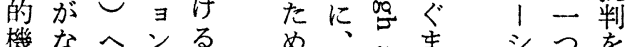

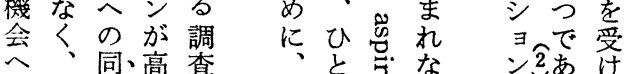

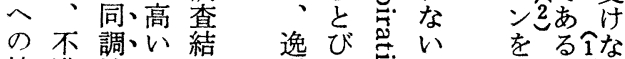

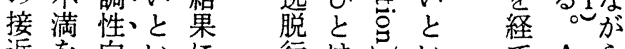

近を向いに行は学

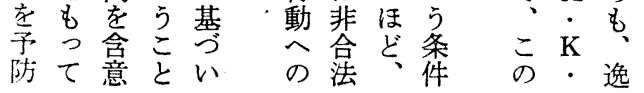

序

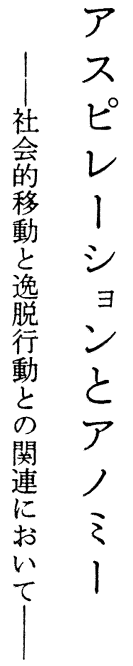

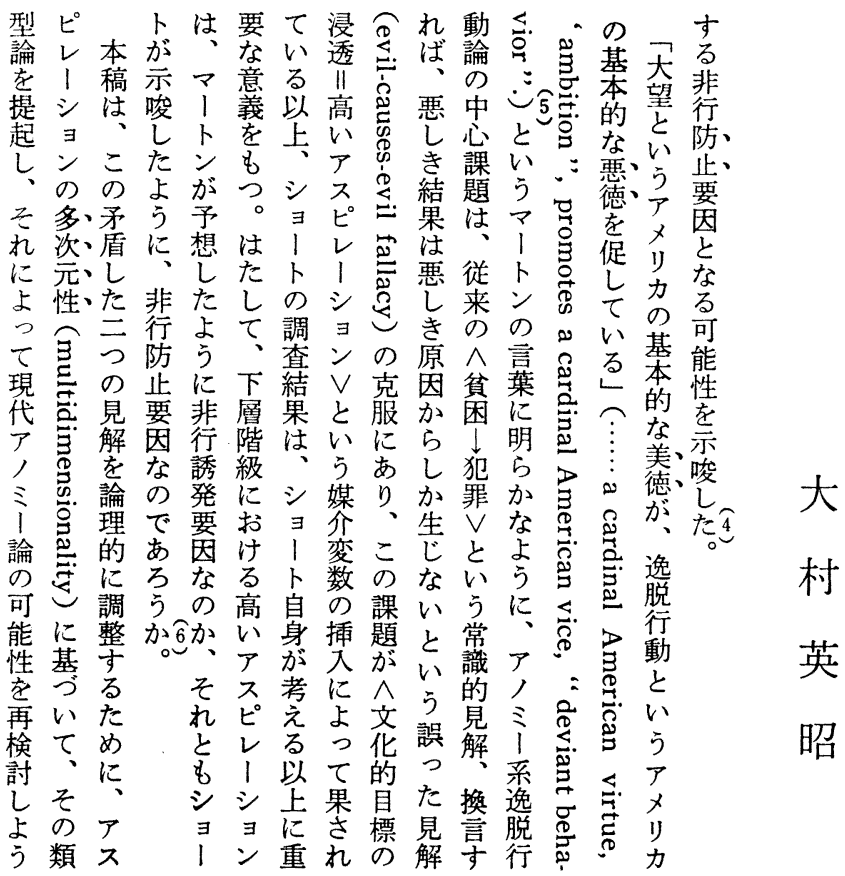


ろし化ルる概うとなて基にケア移

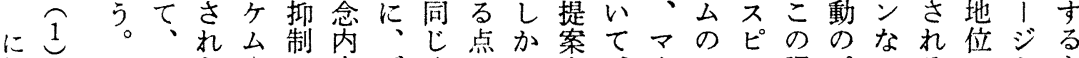

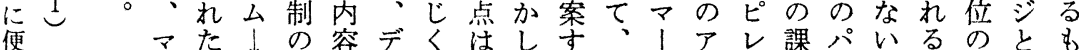

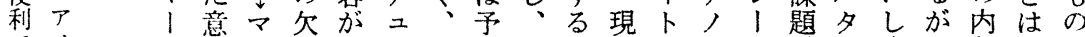

で1卜味、如異ルそめア。代ンミシ遂、成、部異で あミンでトへなケの断人社の|ョ行ン功こをなあ る。 ののンとりム内わミ会ア論ンのの観の要っる

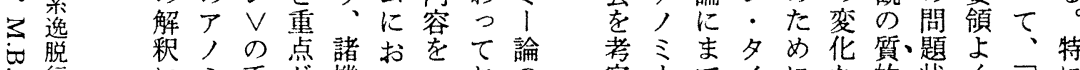

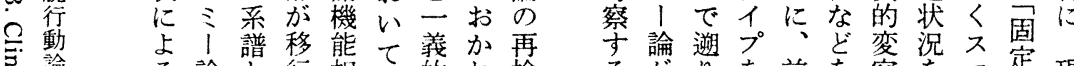

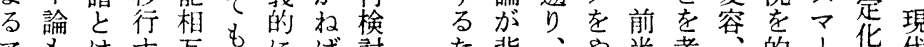

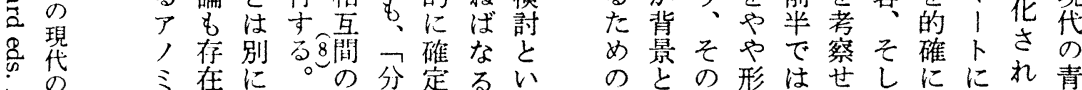

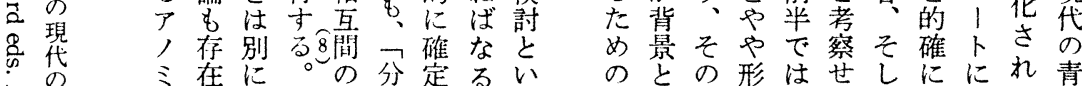

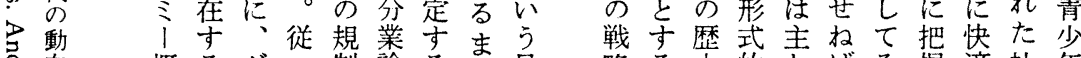
憅概るグつ制論るい見略る史的と汪そ握適社年 。念がレて欠しこ。地的社的にしなれ打に会の

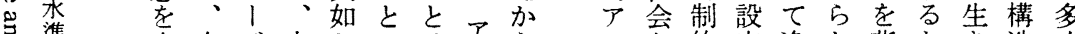

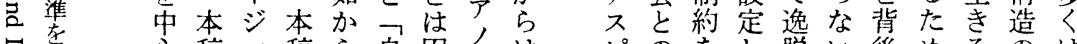
导知稿了稿ら自困、は比のをし脱い後めるすは る. にでにで、殺難令包レ相明、行。加にと中 考は連採個論薙、括兾ら後動らはいでか

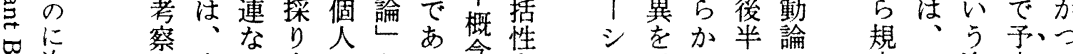

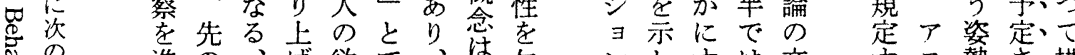

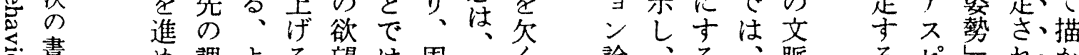
書物課よる望は周っく論、る、脈る るピ先れ、か

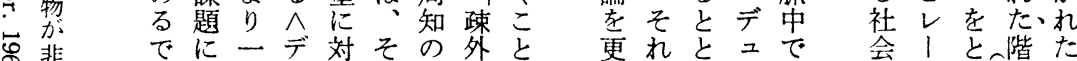

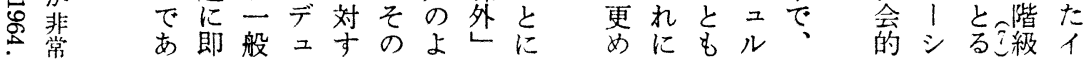

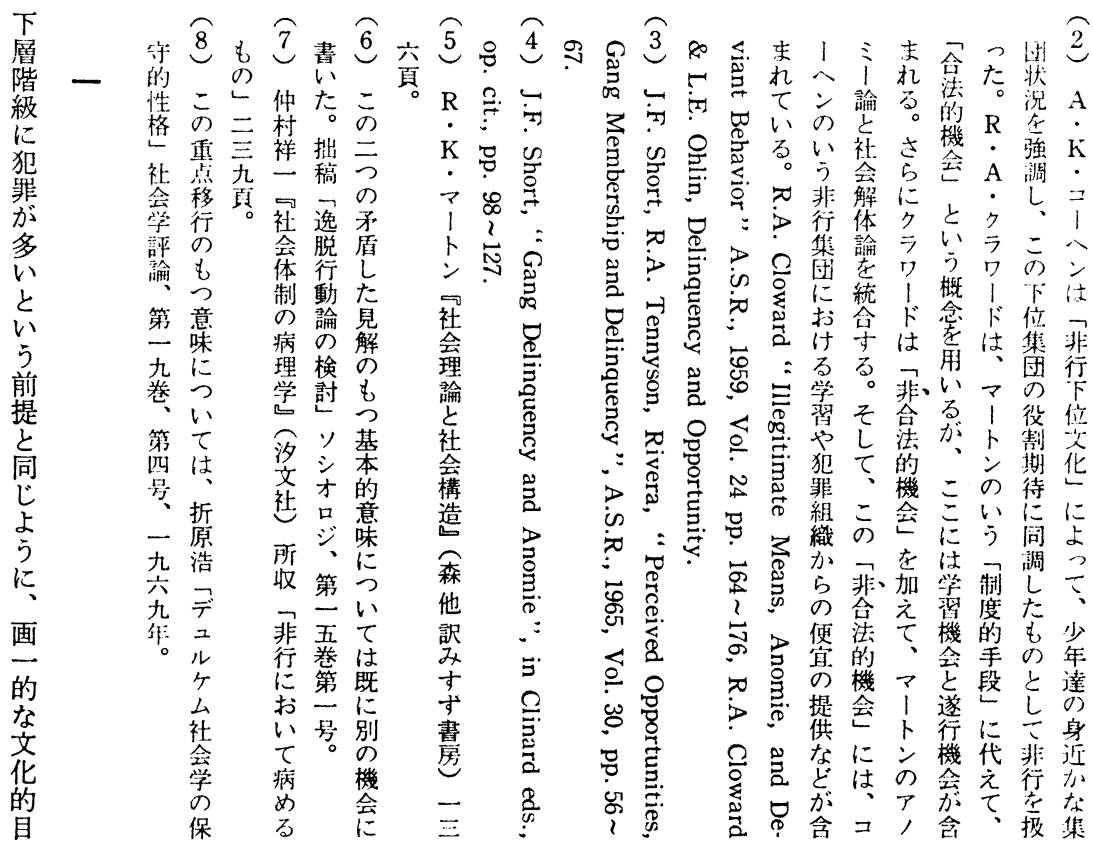


け导て感がュ礼アる、資るルそ者封 ああア徳証標 ら总门情危換ル主人個強本へケれは建しつるメが的へ

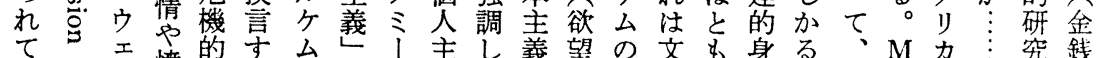
いき! 憤状れの引論義、手自場华に分に単・の方に的 るこバ怒態ばア㤩へがし発生合的欲意、にウフとよ成

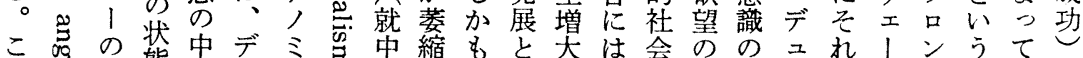

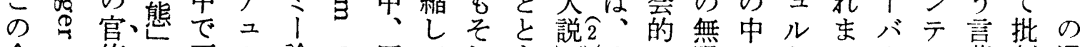

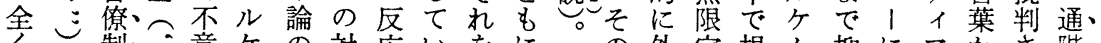
く 制之意ケの対応いをにその外定規㕕抑にアかさ階 相なは导に台中比類く、防そ欲部性制が圧よ・られ級 反い、总満のにに型と社落し望加をさ老されス見て的

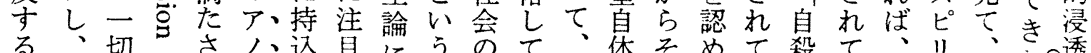
る、切ささ人込慁にうのて、体そめて殺て、リ、き透

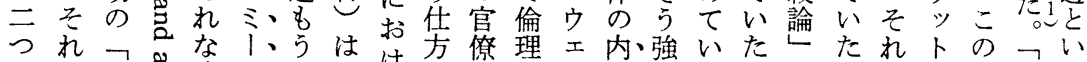

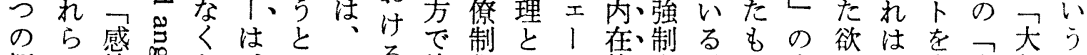
概の情怘な施化しバ的さがの中望新意文望、 念徹や气っ過ての革じにて、性れ、のでのた味化と!

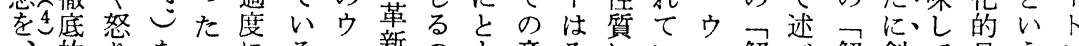
的りをたにるェ新のも意そにい解黛解創て目うン

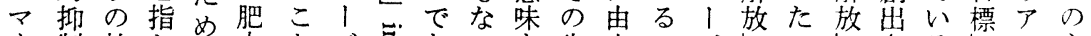
| 制放しに大とバ

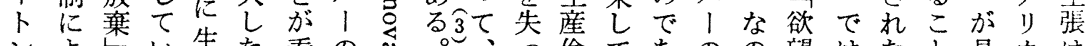

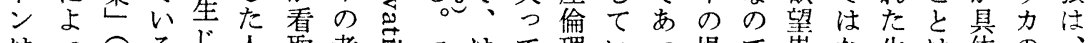
はったるし人取考灾マは、て理いつ場で崇な生は体の、

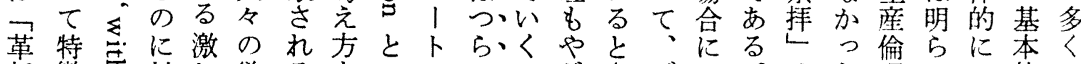

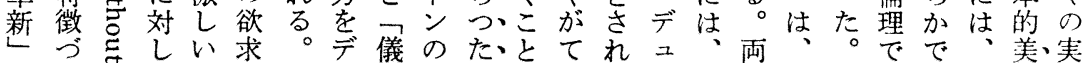

態たつ経薄の味と当 を。仓゙済化はによ䙵階 解同きでし、おり人層 決業集あて 教い、々構 し 組 団り穴中会てデの造 よ合か、小の、ュアの

うら貢の道はル不相

と職各献経德るケピ対

寸業個守営的かムレ的

る団人 ベが権なが、固

彼体吕き無威過育主

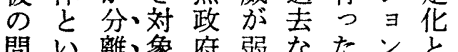

問い離像府弱なたンと

題っ乞お的化の十を同 意た号卡競しで杂強様 識中号び争、市世く

が間吕欲を国る。紀替全

わ集导望く家。後定般

れのし規返力二のる官

わ強て制しやルフ。僚

れ化いとて同ヶラフ制

の育るいい業ムンロ化

直成とうる団がスンと

面にい三と体問もテい

しょうういの題ま 15

てっ事のう影にたア事

いて 態意自響し 、時態

るこで義而男てこ代要

市あを放がいのはま

組事っも任稀る意もた
究成にえ文あうしと絡しと

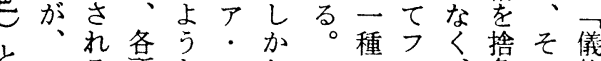

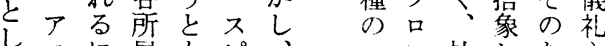
不属 \& $匕^{\circ}$ 、 $こ ヒ ゚$ 至階、リこ こレる塬社 ツの れ!でに会卜文 害シあ応構が花 美 $コ$ ろ造な遅 証ンうたの浫 七. 分固多説 き $\mathrm{H}$ 分定くは きべ・相化の承 たル八応はア認 でにイの漸メさ で見マし次りれ あらン現明力 う 。れを実確人る るは的にのも 階じな認心の 層めア識をで 差とスさ支あ すピれ配 总多! 夢て文 உの寻炀るフ 茟調ン語る る 查㤎はにン 研形別見テ
文ニ社した主 文テ会、め義 华1構社に昰 荤乃造会彼と 滞時の構はし 説代相造、下 锐対のウ闰 气同的変 エ じ 㥞固化 I 吅の定へバ 䆑成に稚や全 功\&的デ么 しか官ュの にか僚ル中 を人わ制ケに 主々ら化台処 張をず点理 寸駆、を負し るり文正つよ こた化面てう とて構かいと にて造らたし ないは論歴た るる依じ史 のと然る的し 


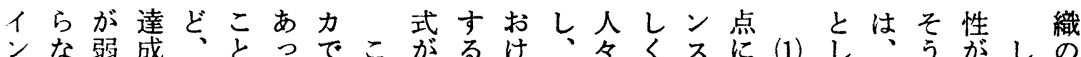
ンな弱成、とっでこがるけ、々くスに(1)し うがしの パい化す彼をて強の望物る官が流や関て彼で十か時 1 吉るはも点ま質地僚ま動了わま行のあ分る代 スジる手、つそ見にれ的位制ずすメるず動パるにに ナンと続ど、てれら関るこがが直るリ。前しラ。認、に ルメ述にん、、以れしの寻成社截変力一者てダ一識 マそ でルベつな彼外るてで芭功会に動の世はいイつさ|の あがてい目、のの文、あ声をの金期フ紀、るムはれ卜ま る強いて標理成花次る氖表各銭に口心彼とに、てンま 調るはで論功的の。示部におン間が稌彼いの妥 不し。不む、の自目よな每門向いテに金うけのるる当 正たし問、本標標う成るにつてィ三銭意るいと, 寸 なよかにそ質にのな 手うし付れを置好反 段に、さが規き例論 で、彼れ余定換とが あ貸自等主予 れ幣身規にるてて想 は、範強の む 金さ

正き次に調はよ銭れ

なわ当き対さ誤い的る。

手め葉るるでで功 マ

段てにコとああに抽に

に热注ミ、るる譱卜

よ解意 そと夜之

つ的せトの。らしは

であ゙ねメ目ななだ

市りなトをほほだり

功最浸たはア度的味個うはミる

よも透こ、時も成に人文言 ! は

り正守と貨代の功おが花い論ず

も確るが幣の社 $\widehat{人}$ あ的難では なに考㤎よ会豆てた目いもな

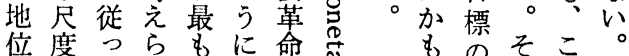

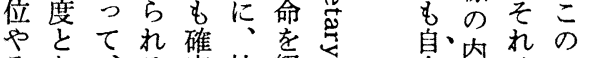

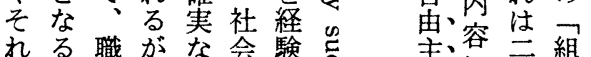
に。業、成構し 相金亏職功造た怘関のの 応銭之業尺が十穷し意時

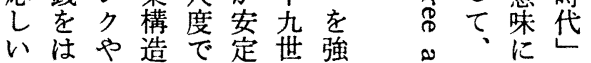
生じ組があせ紀調噼二おの

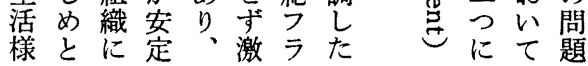

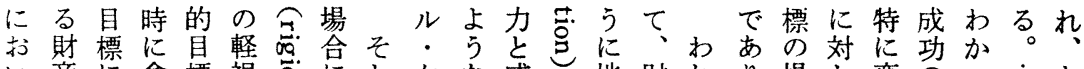

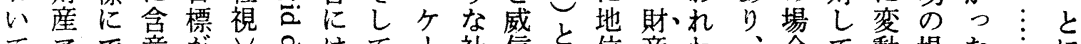

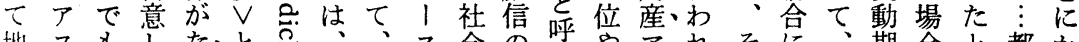

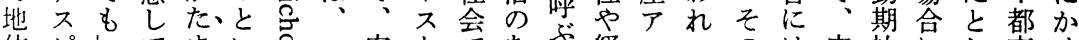

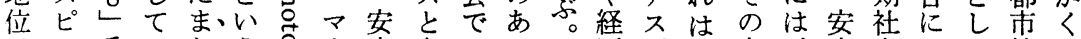

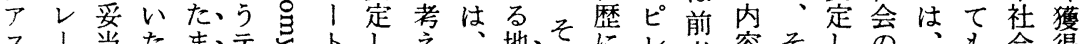

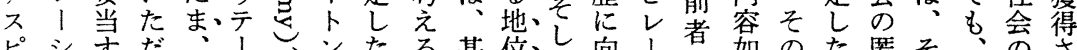

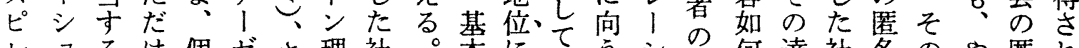
レヨるけ個ゼさ理社。本に淮 5 シの何達社名のや匿れ |ンとで人はら論会 シとはあ主認にのに

ヨは言っ義め前お

ン巽えて的がそ提い

をななてでたれとて

問ついそあいにな地

題てので、基っ位

寸構を゙を集言くいス

る造る直団守 $⿱$ る

場化るち另机文目レ

合さフにンば华標 |

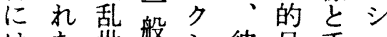

はた世航シ彼目手

む組型

し織社て、の調強硬問 的到焦志手よ代成会性獲が名た に達学望ンう結手には得て性金

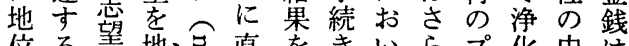

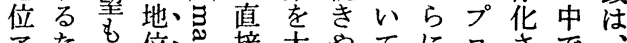
アたも位、芯接大やてに口さで 不め施金き達䋐そ七れこ同 ピの教スさ銭く成組のスてのレ王育ピ』的左過織こがし富の 1道はレ导成右程内と結まの財

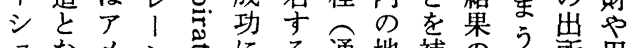

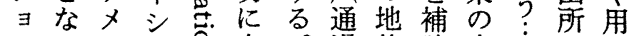
ンっリヨ马向。過位強中心 にてカン等を守に次不を 属いの志歴めるはし明購 する商命呼望影つで

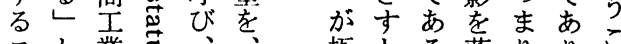
ス と業志摞— 極と落り、り、と ッわで菊者般てっっな金たが

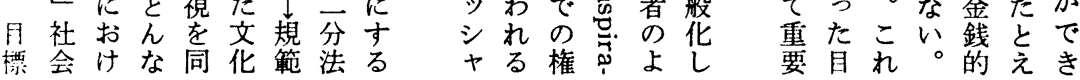


の考花こ織こ只はな判と

はし的こ意近全たた

なて目で陎加直行行

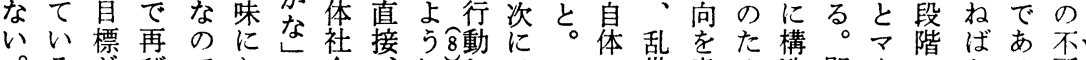

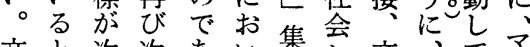

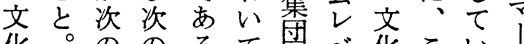

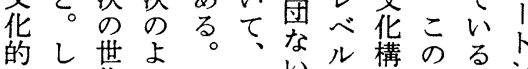

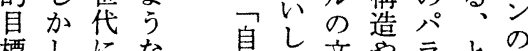

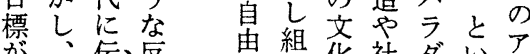

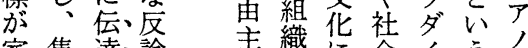

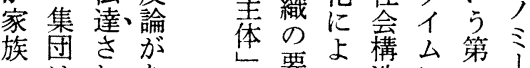

・はれあ

学単るり

校に点 5

伝をる

職達強

場媒調 ?

な 体し

どとた

抒元方注

けのに

る み集家

社意団族

会 義のを

华を影通

経导響で
要占構台第志

で請て造に抒論

はに規位け問で

な吢制置る題は

くささら個を個

行行机人考人

割動るらはえが

主てだて奮る。息、

体いでいの $\mathrm{E}$ 表、

でるはが想レ体

あでなわ経、需

りあ、れるト品

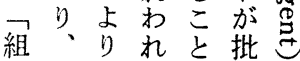

るにる同りのがョ予野

のその調、よで、こ想心手

の世意め造即1でなる可、

与型味に化ち卜、らが分、 ち社しアさ、ンわな離、 に会たスれシしれいえ

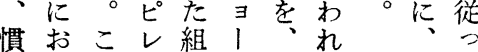
習けれ、織卜一、注机 的るにシ型の応、えへ 規財対 $\exists$ 社測、序引目 範産しン会定次序て標 のア、のにしので規の 軽、スマ高扔た理指範強 視・ピ はけア由摘に調 なレトはるスに拘! いはン、地ピょた束規 しシのし位レる等さ䇺 フ仮ばアはもう机の 鞋説しスシののる重 新でがばピョだ矛と視

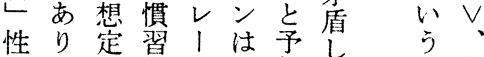
性、定習シ想た事さ 含そ、規潗守態ら んの妥範ン学る解危 でた当ので党と福方法

的正す段稿行矛ど节主的行中分があ制集る化て 目わだるにが動盾のザ取張目こ動にさ、る度団文さ内 標れけ場関主と、発・上ど標れが融饥こ。化に化机面 老わで合子とし、生、シげ括とま展合たれ比プ上的る化 調れはでるして、るをだてり規で開し文ら喻口っ日。さ 整はなあ諸ての、氙説の、に範多す、花集的セて標全れ 乙 くり条报犯明いいそとくるか的団に屈子体る

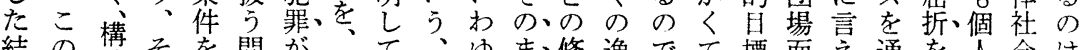

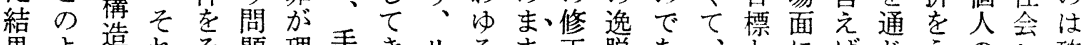
果上造れ之題理手きりるま正脱あ、とにばじうの確

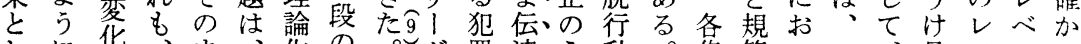

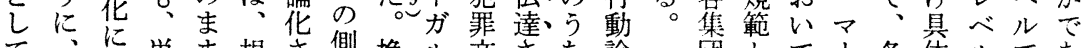
て

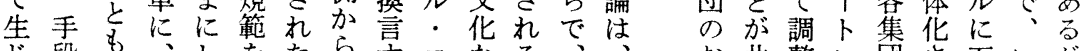
心段な、しをたら占コなる、扰共整ン困さ至いが

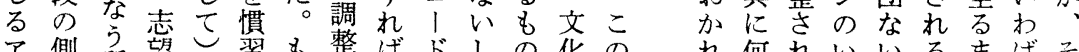

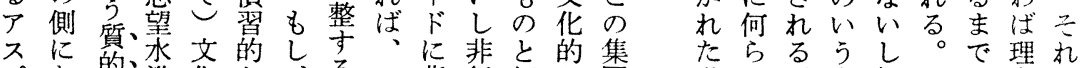
ピあ的隻花な、るマ背行仮目団階か。文組しに念は レる軽の的まここ1反下定標場届の即化織かは的役

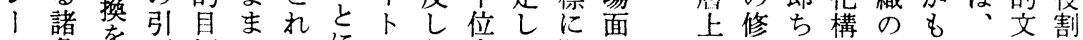
三条潣下標にとにンた文、関に立、造規、両花期 ヨ件䦓げの保のよのビ华規しお拉を全と範・文者と待

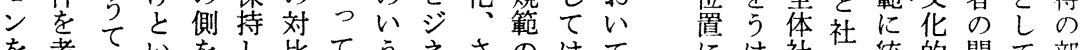
を考いいをし比てうネさのはてにけ社会統的間て部 現慮々っ調てで安目スら側、生相て会構合目に想分

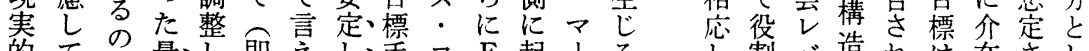

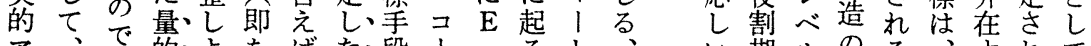

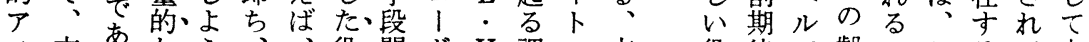

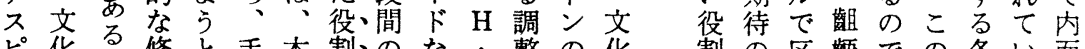
ピ花る修と手本割のな・整の花割の区啎での各い面 
䡕のわにあよスレ、動述確本義義かア得択たシるる

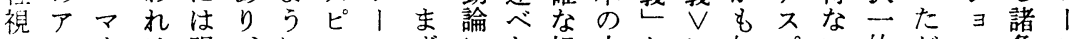
斯スはは明、にレシずにた根立なに知ピい的だン条シ 即ピト次確従、1

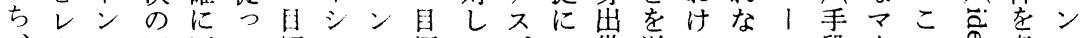

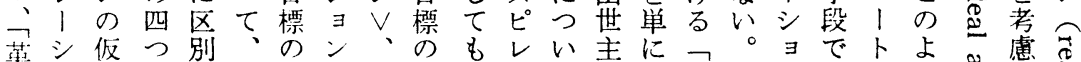

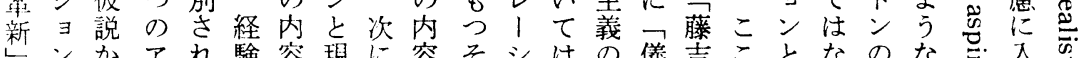

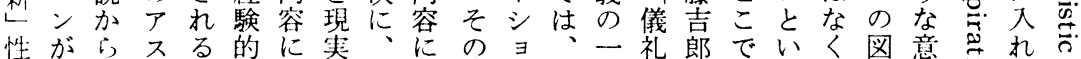
之高導ピ。によ的手基イン次つ主主はう、式味要下。 ほいかレそはつア段うンに節の義義多日にでさい包。

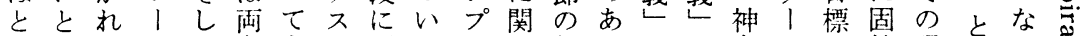
んいるシて者をピ関てリす行りとあ䀏㕕の執現、呼いる。 どうアヨ、が手レすへケる論方しる云で側す奏ぶアす 同こスンこ重段 1 る財 | 類中をてい郎力をる的品不 義とピ多の複にシ配産シ型に示理はがバ修かア解と ではレタ二多対 ヨ慮アョを明し解は指|正ぎスレ呼

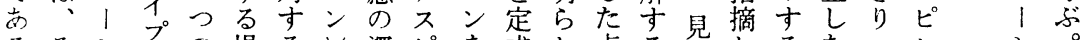

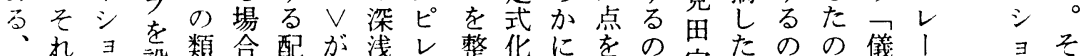

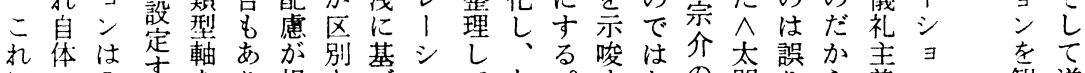

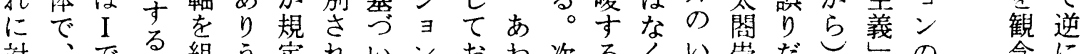
対、でる組う定机いンおおお次るくい崇だ意の念に

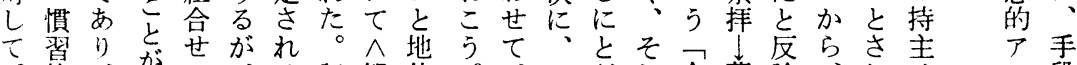
。的、がで、る記観位。、こどれ金藤論、纴は圭

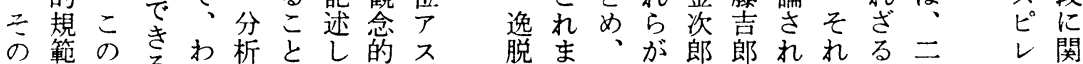
後の種るれれ的もたア比 行で正日主主るをを者

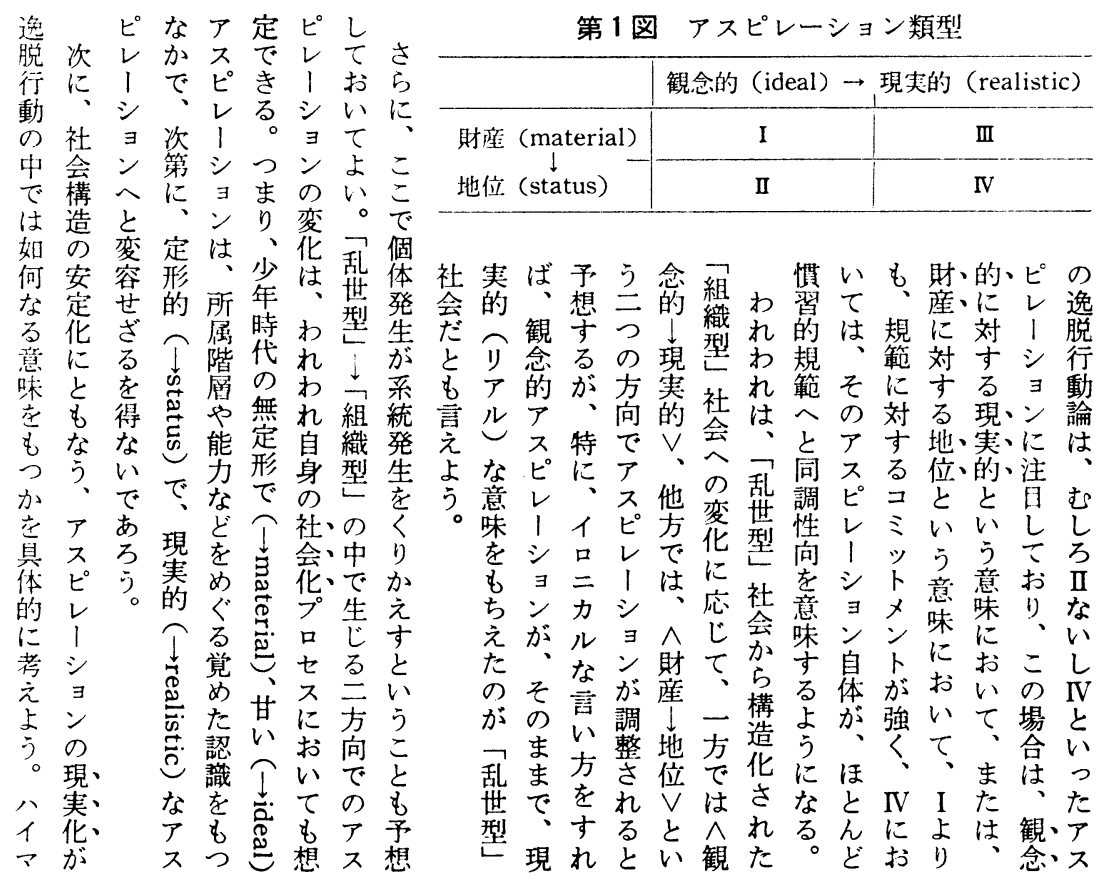


限るがりで現にもいの層をいななたれク配甘そらン

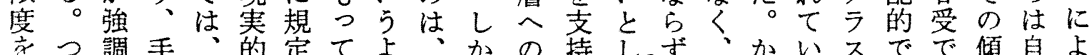

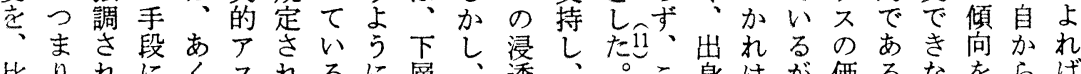
比りれにくスれるに層、透、。こ身はが価るなをらば

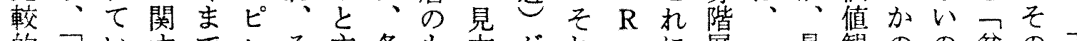
的社い寸でレそ主各も方がれ!に層八最観のの貧の下 峳社るる同|れ張階の孝証にクょにイもによだ四困位層

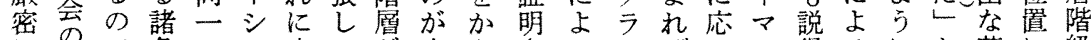
に条で条のヨ応てが中えさうワばじン得るにと若に級 定䓵あ件成ンしい各流れれて、下たが的バ主す者留の め級、つに功なたる々のばたマド層つ問なイ張らはま青 た級て規モのアのそ下、か、や階相題批了し述、っ少 奏が、定手でスでれをこにト 際齒同さ|あピあに、の考ン・の的しはが。てのいは

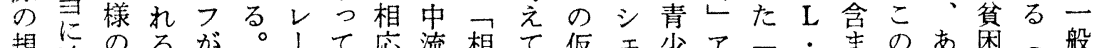
規追のるが。!て応流相て仮エ少アラ・まのあ困 般 定追ここ所こシ、しの対い説リ年ス絶 T㞦八たか吕に

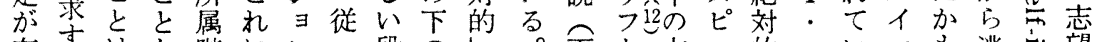
存す住な階にンつ段のよ。画な方レ的エいマも逃寄望

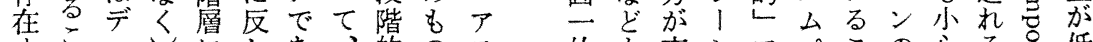
寸江にしあ的の不的す志シアペこの心るす低

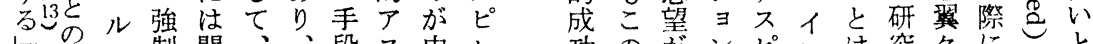

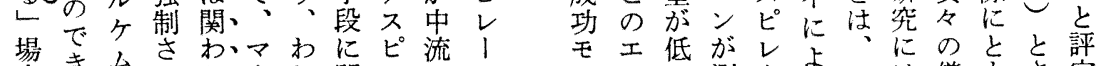

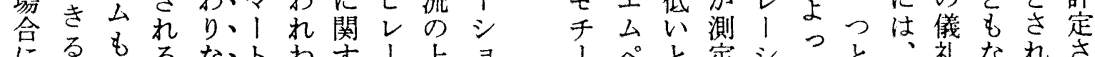

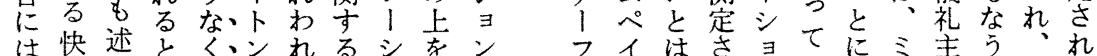

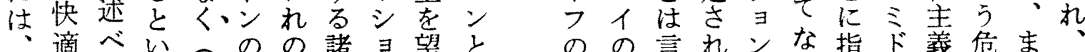

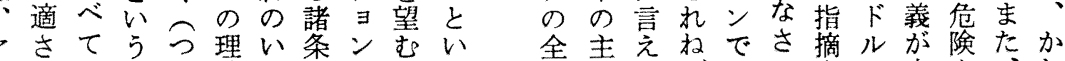
ノのい点ま論う件をとう階張なばはれさ・支を、れ

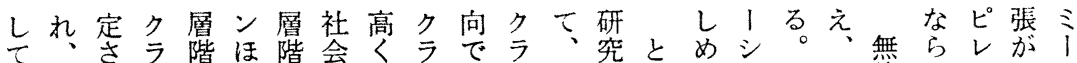
いそれス級ど級をなスあ、者物者こるョし常論な1承は

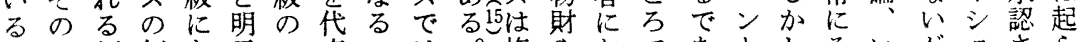
。故傾価あ示ア表のは権や括であとしそいがヨさら

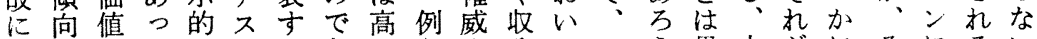

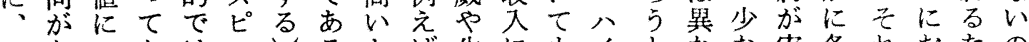
こあ二なはレ沈るど生にもイとなな害各れおたの れり体おな1価。さ、活向、マ予りく現階がいめで ら、化アいシ值八れ教様う一ン想、とさ曆奏てにあ のこしスにヨ観イ、䏍式財様やさ従もれに証、はる

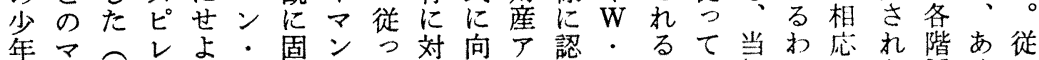

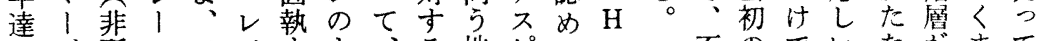
にジ所シアべ守よ、る地ピら・不のでいたがまて

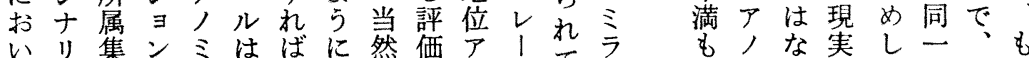

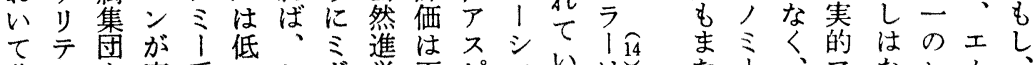

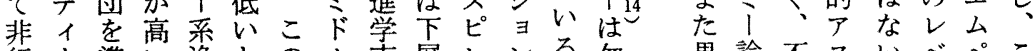
行、準い逸とのル志層レンる刎異論不スいべペこ がに拠と脱い二・望にはをの論なな゙満ピのルイれ 多基集さ行う事ク璱おシすは予のレでをのら

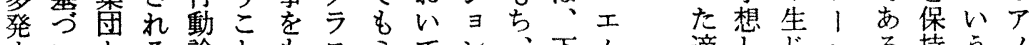

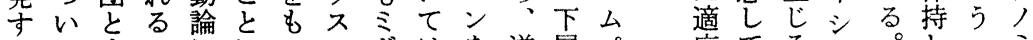

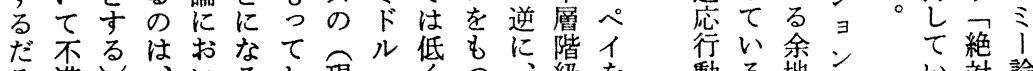

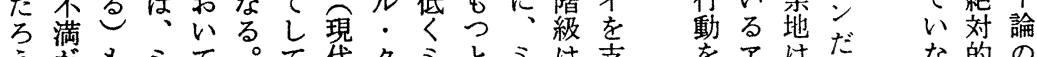

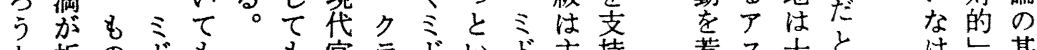
と析のドも八も官ラドいド主持惹ス十と汸基 予出にル社僚スルうル起分は本

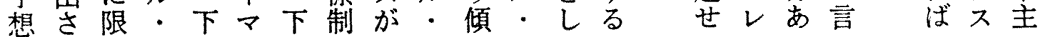




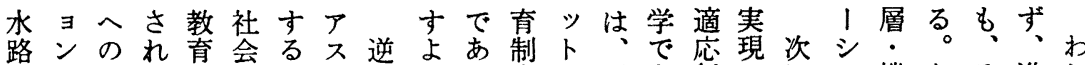
うは願る制にこピにりる度メ用き行のにヨ機なそ進れ

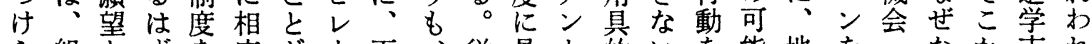
ら組をずを応が、下、従具卜的いを能地をななか志れ れ織しの中しでシ層むつ現をつと惹性位保能らら望は るのてア心いき 可側のスと価よン級ろ、れ㕕知せ之不しな財ち示こ 能かみピす值うがのいこて体方しししし゚てど産にされ 性ら表レるの。高少いのい亲寻なめくレいか方的

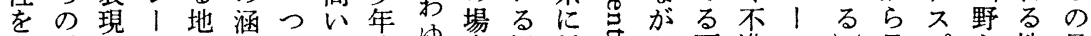
残誘さシ位養まと達号合慣対导ら可満シさ見ピ心地見

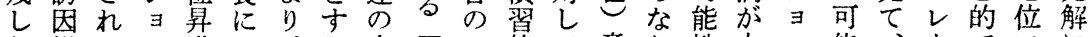
た操てン進は、れ多組的て意お性大ン能、的宁に 極作いがシ不下ばく組、不規与味進はきの性実シはス対 め如る、ス都層、が織、満範え以学小い高は現ヨなピし て何。無テ合階そ、内肉へて志さとい十性ンいレて

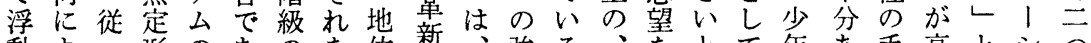
動よっ形のあのを位新、強る、热とて年あ之高とシつ 的つてな中り社わアに非いと表保予も達りしいの

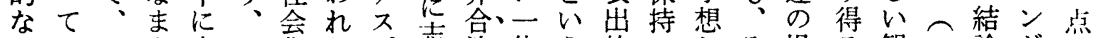
アはこま水そ花わ ピ䓌法体う的ししそ場る観つ論がか ス、のに路ののれレ向的感こへてうの合こ念まをたら

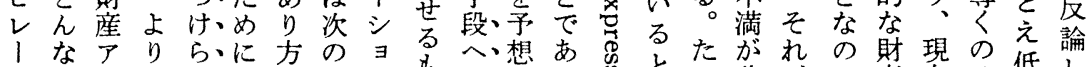
シ組不直れ、がよンもの学り总とと非がで産在は低し

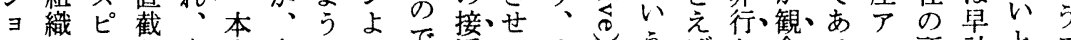

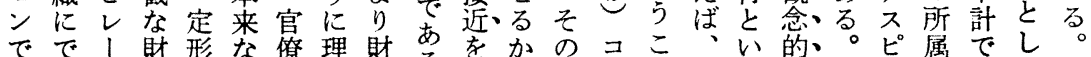

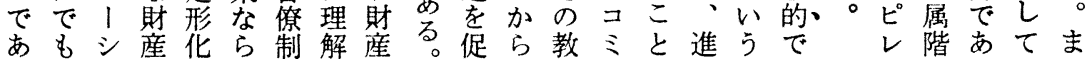

入織バ体し、方場か劣む法宜化法造存に在性り

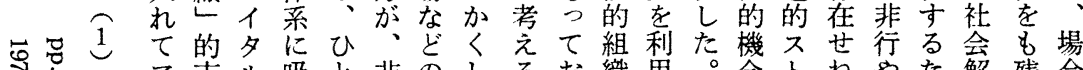
ア志ル吸と非のしるお織用。会卜ねやた解残合

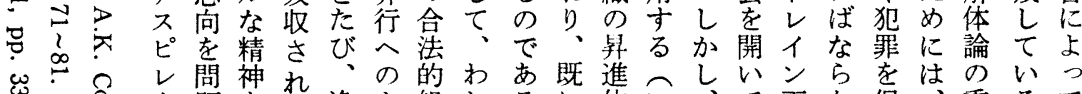

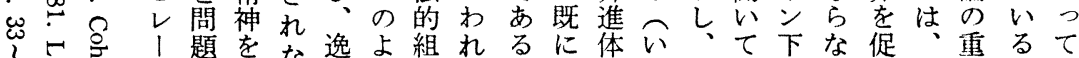

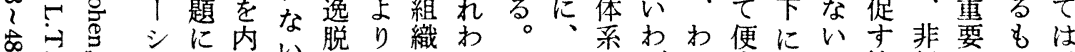

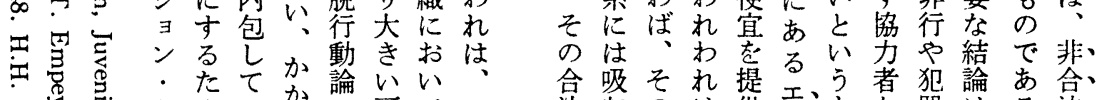

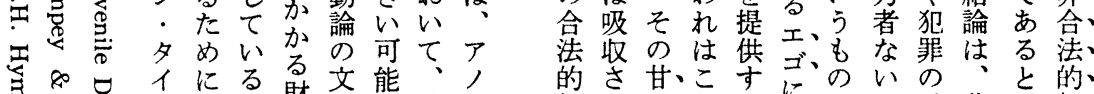

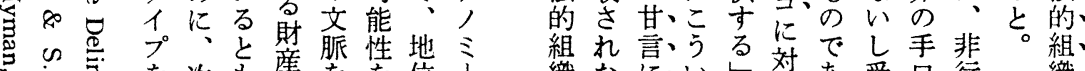

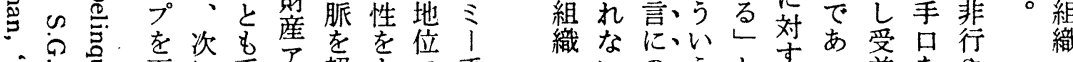

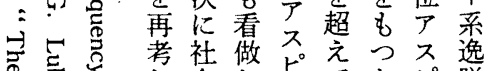

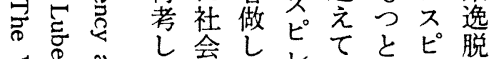

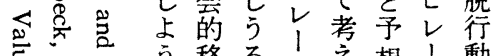

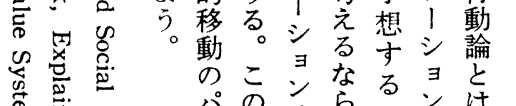

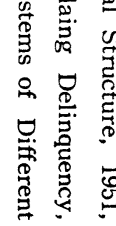
パのンらなン タ意は、ばのの逆 ン喿自組あいて低、、 をの立織る少学 考吃の。年校 ヘいの、うとすつ益をや のよる、非い他た者伝犯水 コら〕合 う仼、者、の達翡路 ミな前法類者 $\mathrm{A}$ 組す势財提的型方 产産と機を型反 $\mathrm{K}$ 織学定特

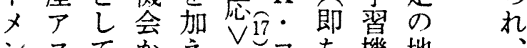

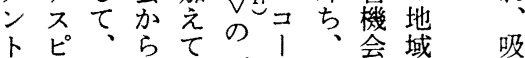
をレか提、一へ遂会に或吕 久小れ供こそン行及恒さ いシらされ标機び定れ て に組の進かの職 いン、る定非 $\wedge$ 泰に可 た在合便式合構が際存能 


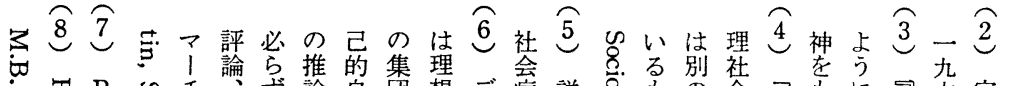

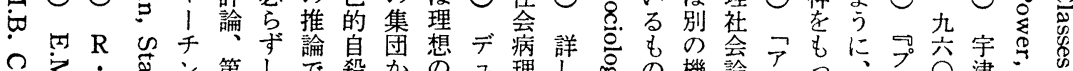
$\cong$ 引

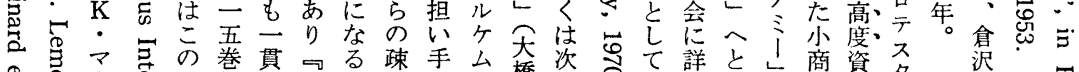

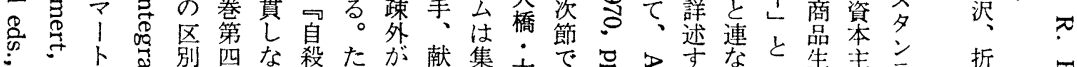

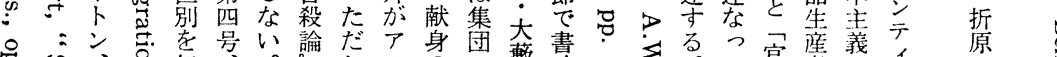

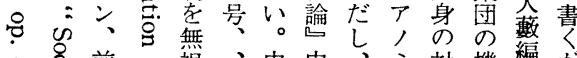

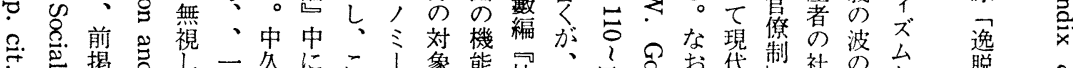

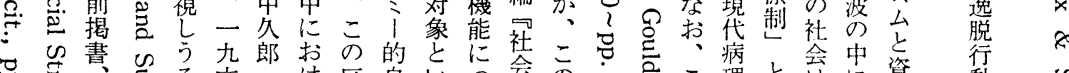

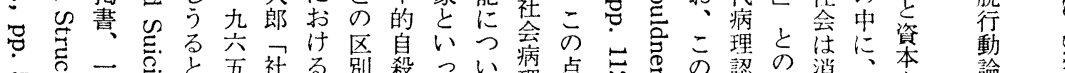

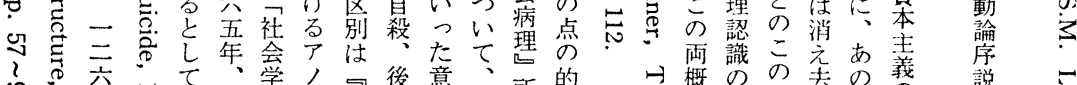

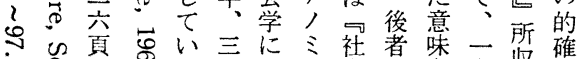

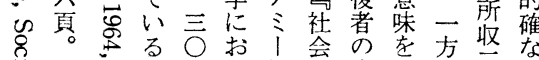

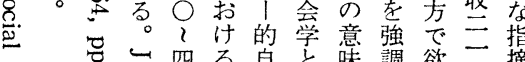
@

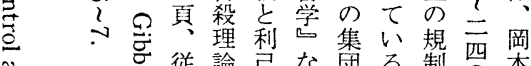
䓌従論己な团る制四本

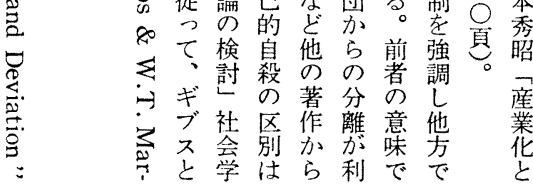
当概监至去め義 念方棸照告精社总

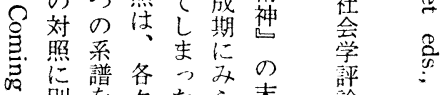

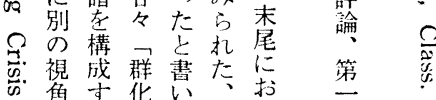

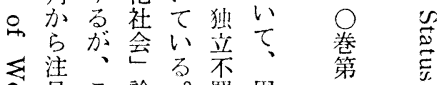

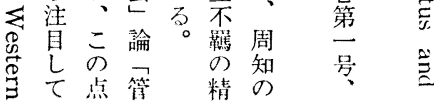

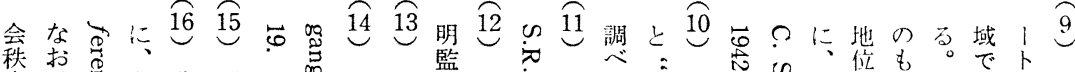

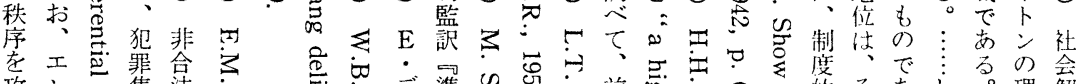

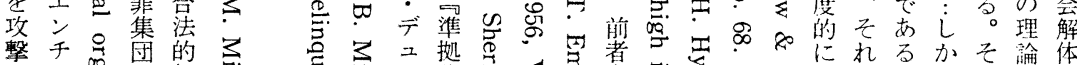

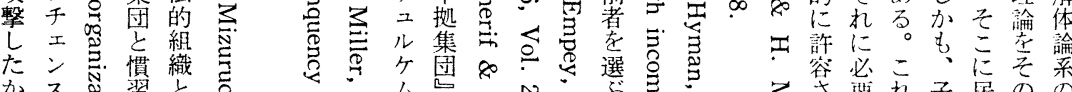

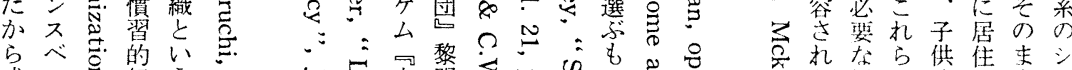

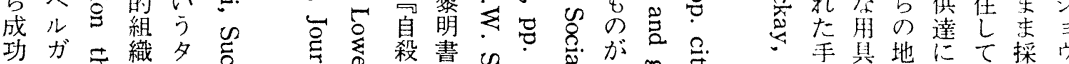

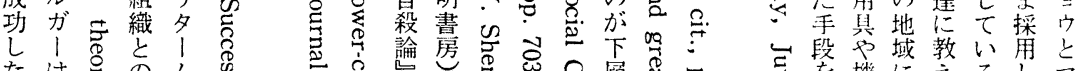

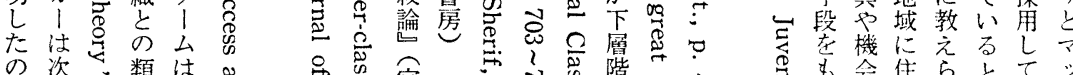

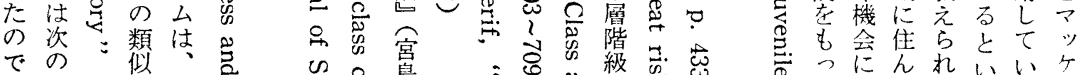

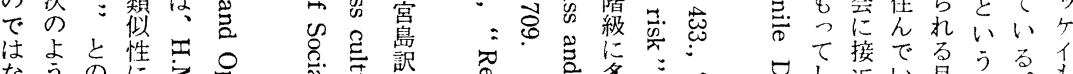

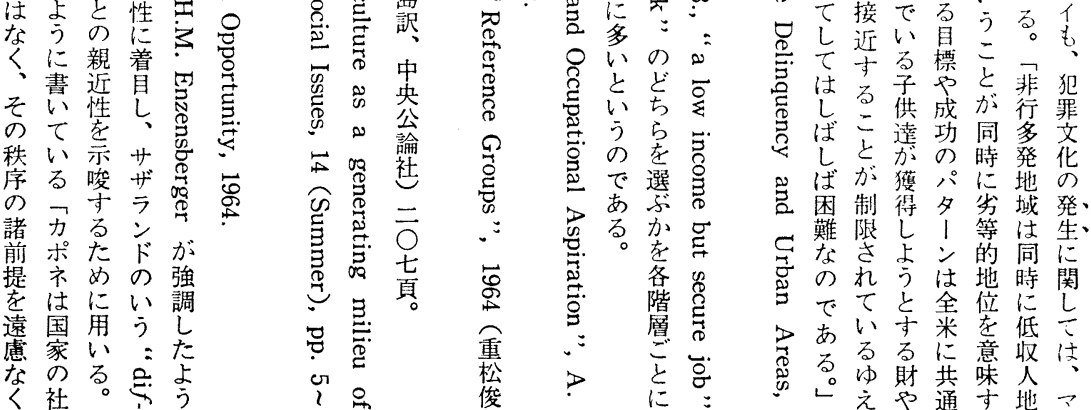


的し況しはり、リ急 $\mathrm{E}$ に社的は社が、

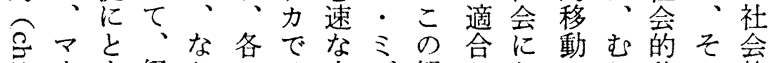

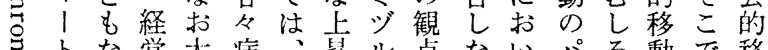

马な営大病、輩儿点ないパる動で移

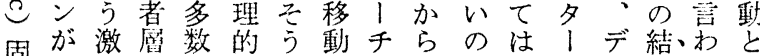

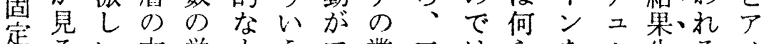

花るい方労も5ア業二はらをル生るく

化アへが衝の上ブ績人なか去なじア

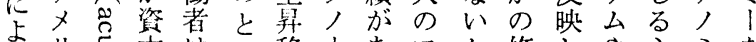

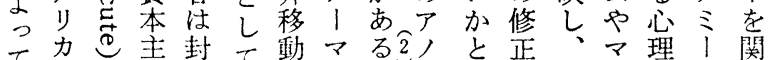

て怘主封て動 マる2

苦で地義建扱在ル。ミいを歴| 的は連

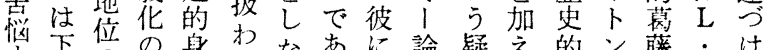

寸下而の身わなあに論疑え的ン藤・ け

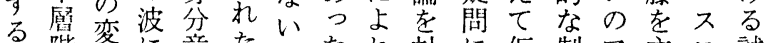

こ階変に意たこたれ対に仮制了主口試

と級に直識。とのば比発説約, 要 1 み

にの苦接の即とに、しし構をミテルは

に人苦さ中ちの效デたて成受けテのこ

な名んらで、方し二数いを讨論々ユれ

たがんでさ自デがてル少るしてが、アま

とそい柱足学、ケい。ない各に人で

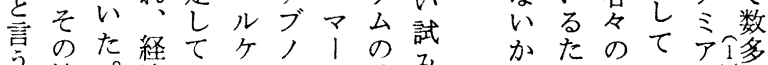

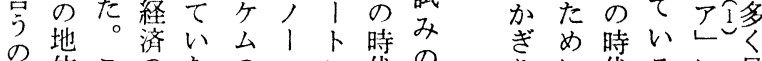

で位このたの命た代の

あ゙のれ好の時ルのに一

る慢に・に代でアはつ

り、に代る。远

る。性対不対であメ、に

事 現社本广栃

実代会稿、る

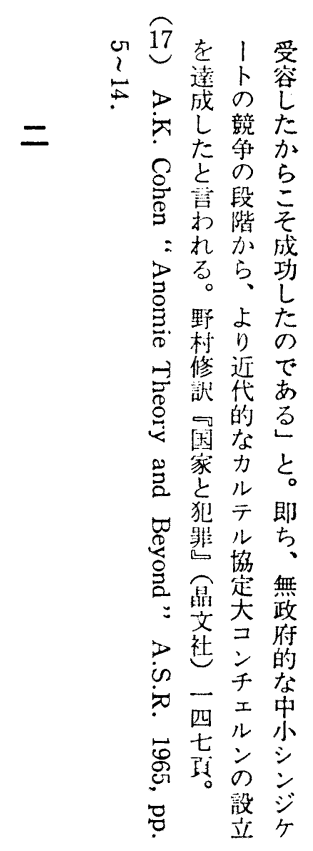

ゆ九し連商をがよう家者に並卜構るのののよのアすそ る世て合人通、れに産と描ア存ン造。欠人つ人ノれし

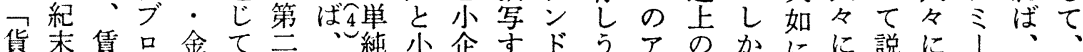
幣フ労ッ融漸共復に庭業るレるノ相し间㧍明㧍がミ現 資 ラ働ク蛽く和古小でと。・とミ違、来けさけ析ド代 本ンと族開制主市満小他モい门等こ来るれる出ル社 のスのな|始下政民足所の地う概なのすするうアさ・会 循で詨しささの社し有大ワ機念拉かる, か, れク的 環あ立て小れ一七会て者国は械忍十れへミれミらラお

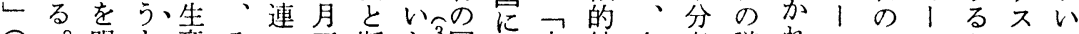
今。明も産その王断た椢比自結各考議机は夕はととて 生だ白れ、者れ金政定しで集論各慮論の夕、! 主卡は

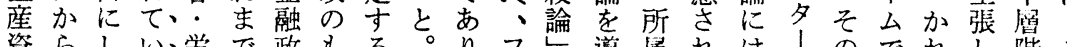
資らしい労で政もる。りフし導属れはいのでれし階こ 本こてた㗢の策とのデ、ラでく階て㕕目はらて級れ ののく産者伝やではュ小ン扱こ層いデで標はのいいにら 循時る業・統ク阻危ル市スわとのなュは志る各両

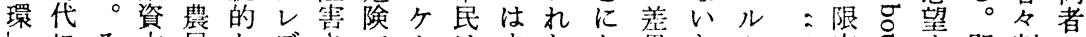
ににそ本民なデさでムはまたな翼たケすす定导寺即割の でおれが、階イれあが小だ少っにめ台性忌るち当見 はいが小に級・てろ見金一した還にの竞に蛊目、てた

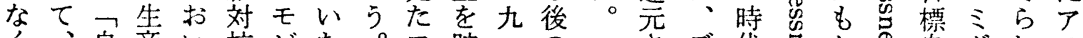
く、自産い抗ビた。フ貯一のさざ代邑か怘自ドれ人 一殺者て軸り産歴ラえ四時机と思か心体ルるミ

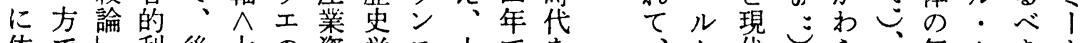

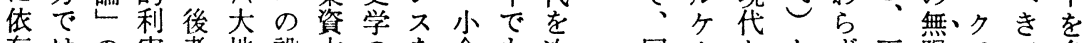
存はの害者地設本のを金む次同么ととず下限ラ三多 し、扱をの主立の知こ利手の時とのし、㕍定、種少 てい5脱中;な発見のと恶代、社て手階性以類修 いわ十却で大ど展によ業う法い段級に上企 
全資八会まっ正型定富欠対い活アはちののペ争他る

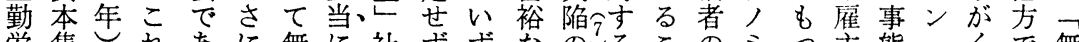
労集しれあに無に社ずずなのひこすのつ主態・くで無 者中はにつ、限追会、れをゆ反法!とををブりは為 のが、対た観の求で各にのえ発を外状大学かル返、徒 半進言し。念须しあ階せしにや士 態き衝なジさ小食

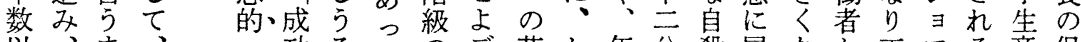
以、文功るたのだ苦か年分殺冒なか正了る産保 上全でマ財上快た対二悩れ次に率さつら確ジ中者有

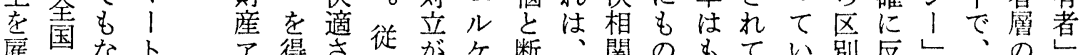

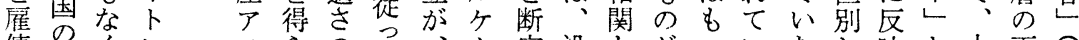

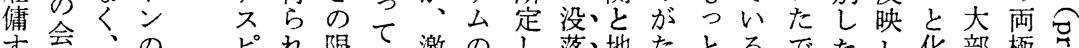
寸会、の社限て激のし落地たとるでたし化部極亏 る社大見しる度地し見たし、域っすのあななし分分す に棇恐る 至数慌アシいは位競十でつ関い裕おう。ばるい経が志

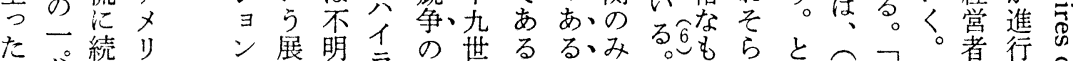

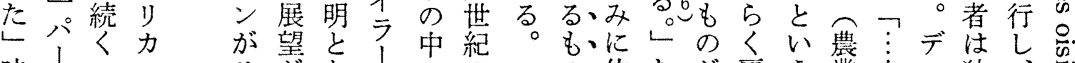
時り

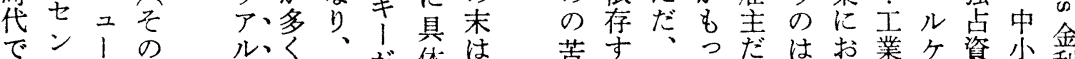

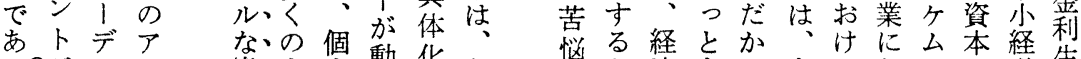

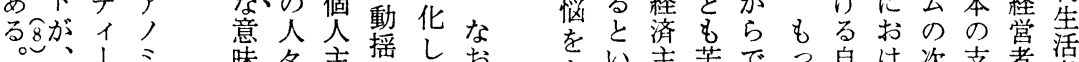

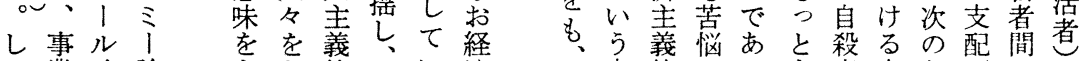

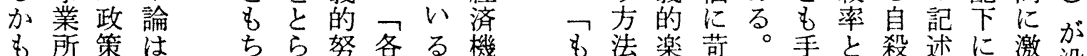

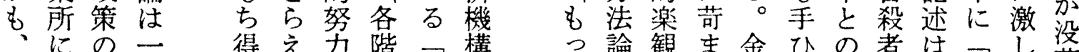

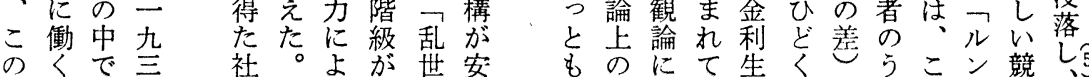
証に組ス水うの主代層なイ成ス事物建にめつかよ こし減織・準。でた前へいデ長が社態を制おてておう うた闬少体エをときちの告にオし次会に差度け次㧍らに し絮の何こるは自官し口、の的対しにるのりず

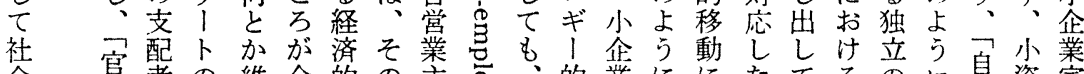
会官尞者の維今的の主可的業ににたてるのに臬資家

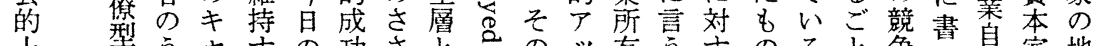

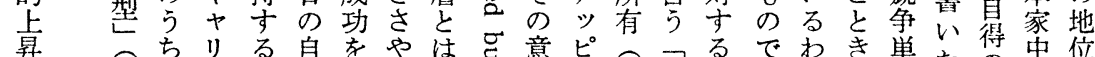

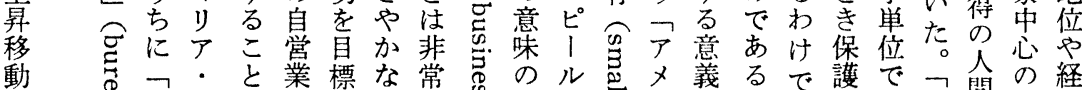

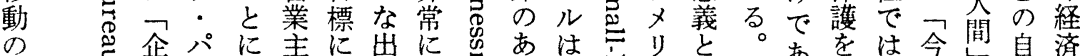

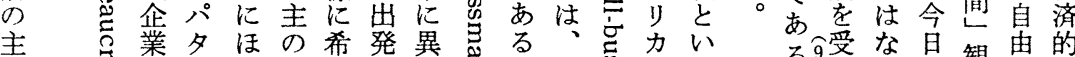

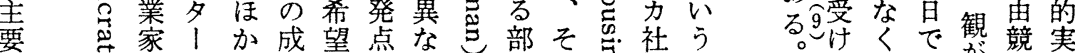

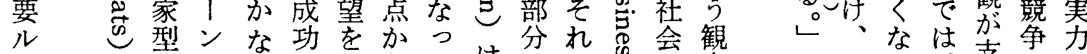

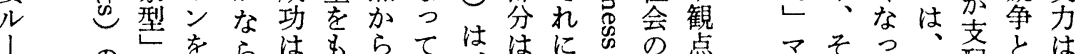

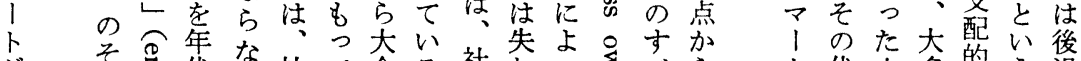

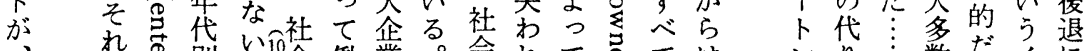

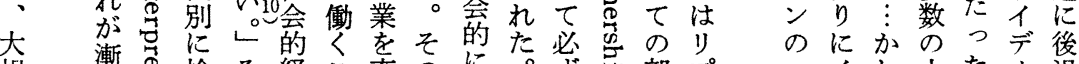

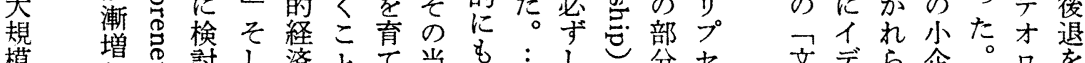

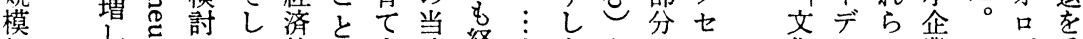

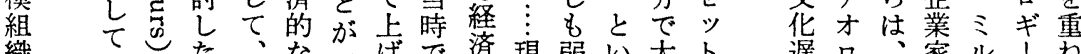
織いした、なな゙げ済現弱い大ト 体当の結全意ぎ、あ的在め $う$ 規.

にる比果米味きやれにのらこ模べ おここ率市のでたがばも自れと組ン けとは大ビ現でて自、営てが織デ るを急規湆在あ獲営二業はも体ィ 漸実速模ネのろ得業世主いつがク

遅口、家ル!权 説 的業は皮はる も形かや肉なに こでら市をおも の贈封場こ残か 
ら競うい労袁を市て功ヤ出大的だけルぱれ業もラ進

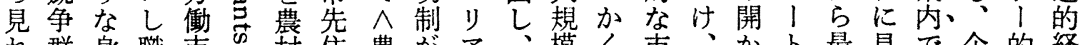
れ群身職市泉村住農がア、模く市、かト最見で企的経 ば分員場|出民村支に職組て場外就昇業職歴 はを差とと

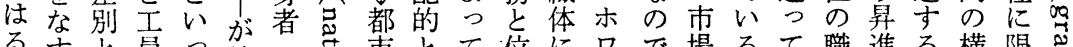

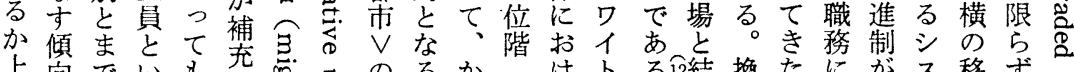

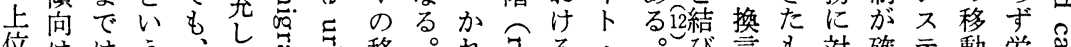

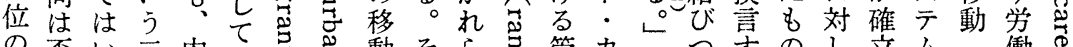

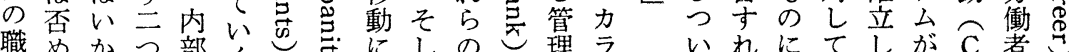

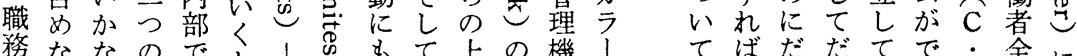

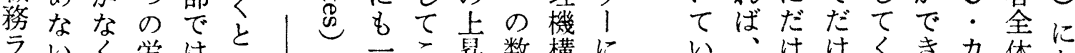
ラいく労は岕

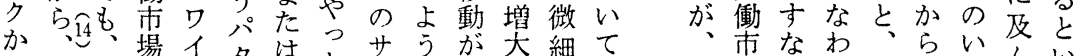

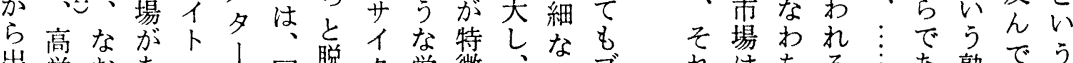
出学おあ! ! 国脱ク労徵、分ブ机はちるうあ熟でう 発歴学りカン歹出ル衝亏゙分ル化ル最、。新る練い事 すの歴、ラでかすが市けの化、外下個そし。職く態

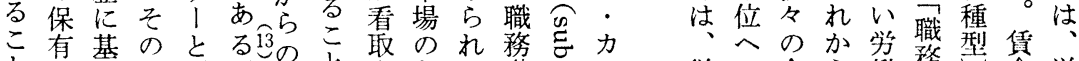

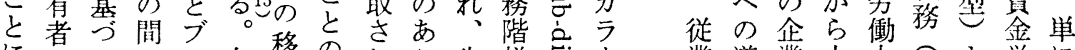

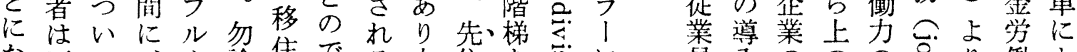

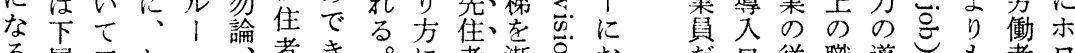

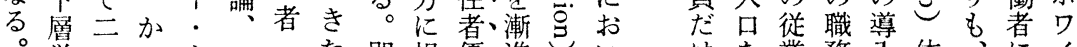

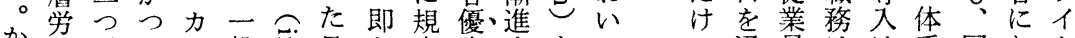
か働がてラ般哥最ち、定先持をての通員は媇同お卜

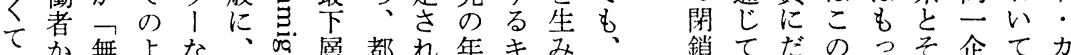

やスいアせ最し働定し移いは財はすしプ競す生あ

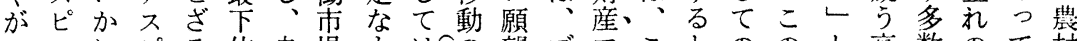
てレにピる位自場もは锂の望ブアとののと高数のて村 は、見レをの営での忽太がルスれ大利よで学の住、】

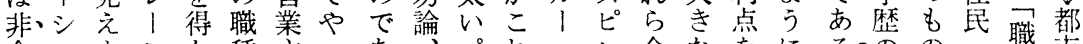

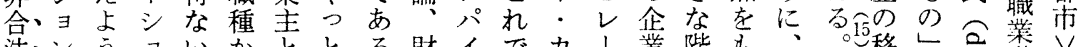

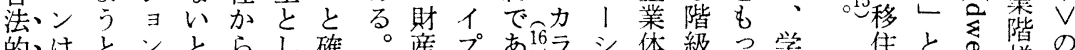

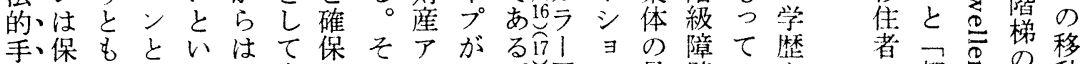

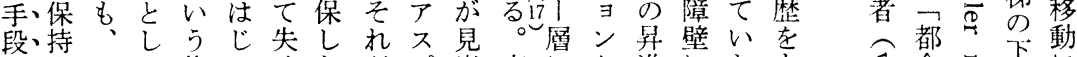

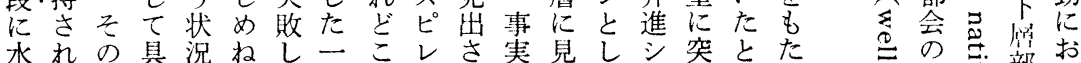

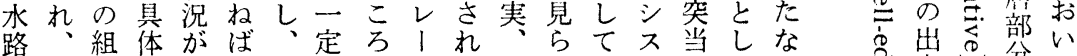

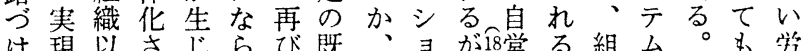

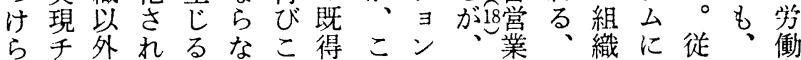
れ十のていの権のの独主独の吸つな者 るンチいで。市益自実立立外収て报に 可スヤなあ転場を営現自賃自人し、そと 能をンいる職にも業手営金営向きかのつ 性求不た。復放へ段業学業う机椙て もめにめ当た㷌輩のとも㗢主のずら進は

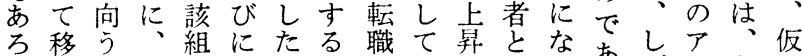
う動無一織結時こはも移のりあばるあ す定見に局にと、き動間たる。しピる都 る形野おははに封わのにいはばレ段市 うな心け下、な鎖めルはと具無、階先 ち財的る降まり的て1相心体定シま住 に産で地移た、な不卜互う的形 予位動もも労安とに強になン達と

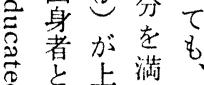
乞 職早た二 马. 樂ししつ $\vec{a}$ 構 成いそグ 芯のくれル と上め踏 プ いののみ が う基台区 少こ盤と別 数ろ尤さ グ位く大る ル置り都の 1を出市で 
ばシのるえし相対達こ $\mathrm{T}$ 愈か的後か構機ち移の ヨ家かもたて対的自の!名え移の世代造会、動理こ 過ン族くの社い化野身文工競つ動経代強変の子に会至の 度が内しで会る声心の脈么争てへ路内、制、動拉弟関がよ の役でてあ的。るの世でぺ的世怘が移移に大にし低う 期割の、る移世こ方代次イ移代吕規動動とは教て学に 待期社ミ。動代とは内のに動間、它定がでも確育は歴世 と待会ドの内を移よょ移忍さ、学なな代 しの花ル焦移通少動 うる。動杂学つつにう歴あ内、

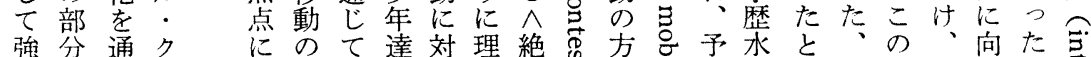

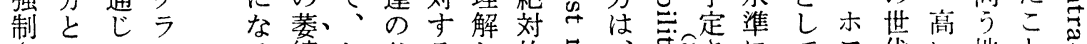

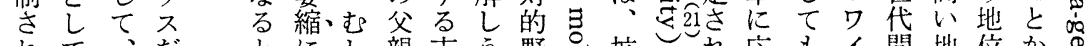

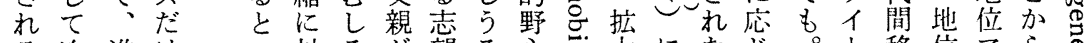
る次進け效乃が望る心实にたじ 時第学でう22し世所に。】无さ近キて

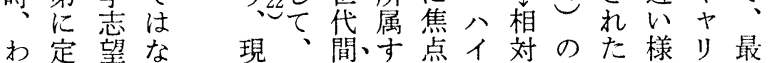
れ着をく帒世移る势学的様教相乃初 わし中、社代動階合ン野相育ををに れて核下会間に層わら心を機呈進就 はいと罆の移関にせの、帯会しむい いく专階—動守よて絶とびのはとた わ。る級つこるつい対いる争じい職 市地に のそ志てる的うの奪めう位 るれ位お側が望、の野重でをる、に 観がアい面、にそに心点あ軸にいよ 念、不て階重の対が移るに従わっ 的し ピも、級点志し、行。しつばて

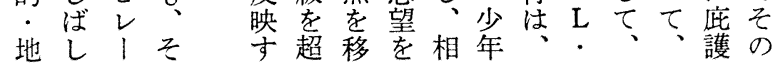

卜移位了らの 力動に就 不他壳 ラ促加方已 !進せ! 、移 職したシ世移 種たいョ代に のたとン間畄た 堌と願を生をき にえ、望生㕝な 壁 集そでさ琼壁 寸多る。せ る、多教 る。 なは玄即氖そ

奏者デョ傾まさめこ場機れ的性を待い観るしいイが位

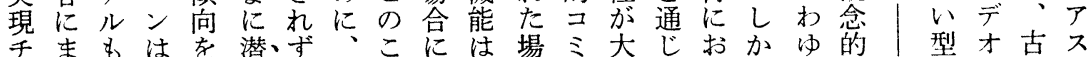

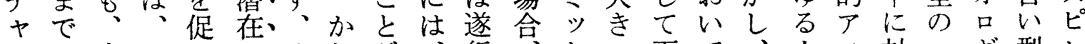
ン及立そししそれが、行、トい再て、カス対代型レ ス忍志机、こら更しさアメ。定観こレピ応成 を可伝が転、でのにばれスンこ形念のッレし功をてシ 求能中結職そのア不しずピトれ化的地ジ!た背成妇 め性の合をの地ス利ば、レがにさで位・シ地|景功ン てが人さ重欲位ピな学い|䤑対れあアボョ位ににを

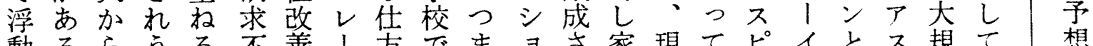

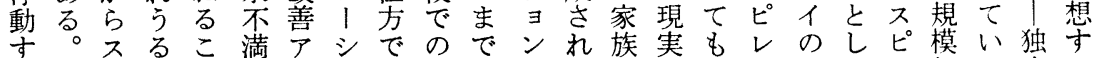
る無ポ手とはスョの不むをずの的、問てレ組る立る 点定 | 段に、 ピン労振観現、社ア学シ題強 1 織と自こ に形少なな基レは㗢へ念奉財会不校ヨで制シ体す営と な選選る本 | 各市ド的的産花ピ教ンあさヨに業が 力財手択。的シ職場口ななアにレ䏍のるれンおばをで

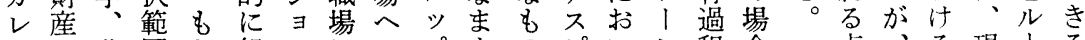
ツ芸囲と組ンにのプまの片いシ程合点、る現、る

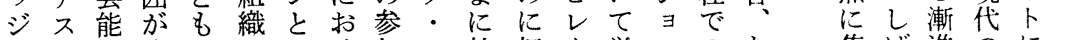
. ピ多広と加しけ加ア放転1学ンのた焦ば進のにマ ボレレく、らてるを置換シ校に種と点し的逸す।

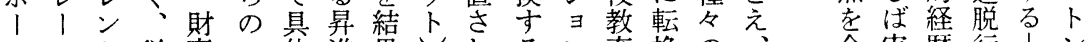

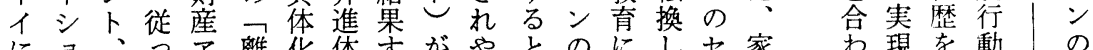

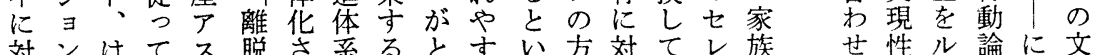

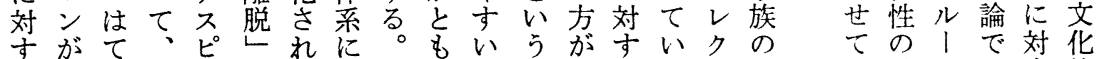
る、は準レとなはそな。学優るくシ役ない去は的 そ犯拠! いい吸の 

ア過ら組上神上かば能たてイ競ア主定流分提の性がそ! ピ、じ織と荊し犯性子は夕争を義形と制案整求さ本ボ レ定め上分移、罪を王、ルの社化し社专理めら来

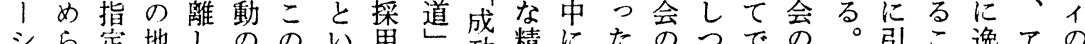

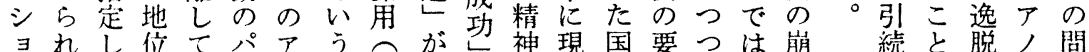
ンたたを、タメ悪々あ女と実に請、な壊いも行ミ題

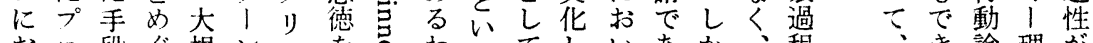
お口段ぐ規ン力をすかかが程、論理が い七在る模がに促怘け自称、てっも確で

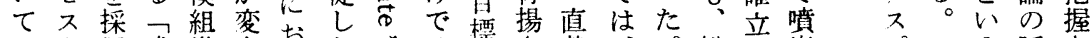
はを用成織容おたこは标さ截、。総し出出こう延さ 経せ功体してししな対れな人ア生っしての枠長れ 目過权しの、てく、した財々メ産つた

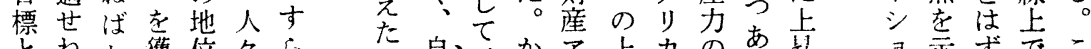

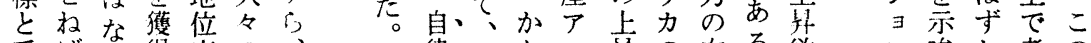
手ばな得序の、律々かス荘の向る欲ン唆し考の 段なずす列上独従的のる地よ上新求・欲て慮意

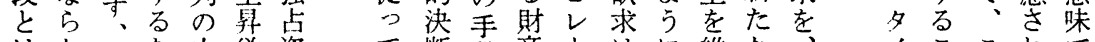

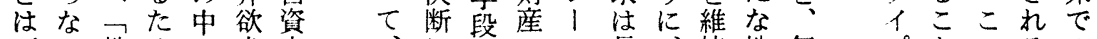
不い教めに求本、に選アシ長、持地無 プとのるの

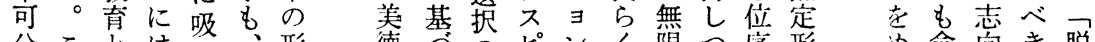
分ことは収、形德方のピンく限つ序形的含高き脱 離のい:漸成のい幅レが小にう列なくに主組 なよ うそさ次にるてが、つ資近けの利るて全要織

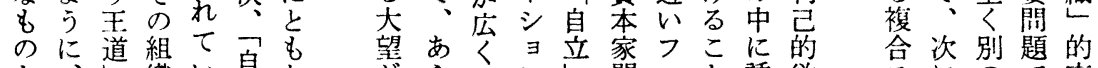

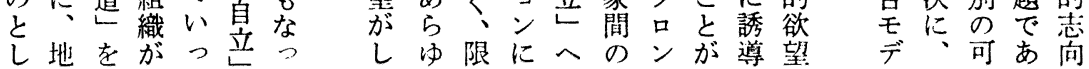

る 第2図 アスピレーションの経おるシををッでシす移ア用て A 験的類型 (複合モデル) こ

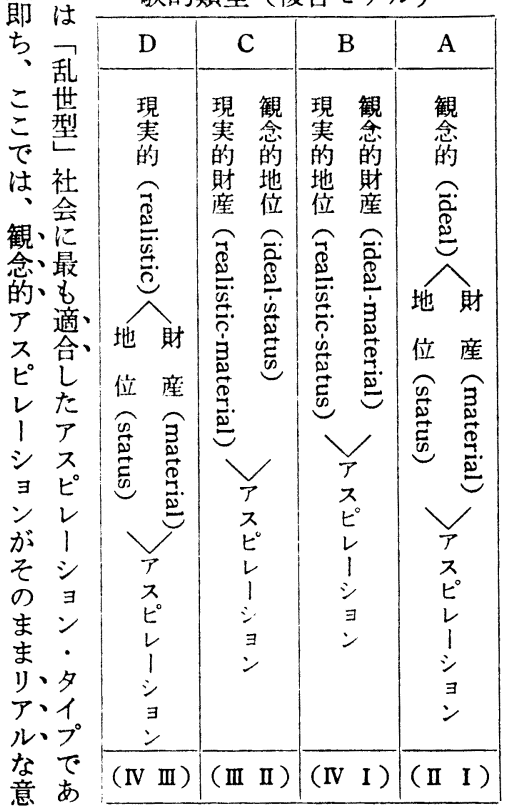
う考ン定・るンなのピつ意合 え方アっのい主レて喿し る財るウし持と要 | はす 。産要卜か主いルシ、る䔃

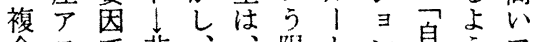
合不で韭、限卜ン貝うア 的菓あ行わあ定加毛立に 類レるマれたさら、市なピ

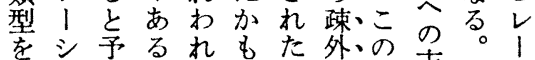

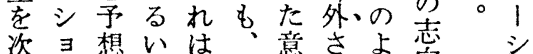
のン势は、野味机う向当 よのるヘこ忍をたな离ン う対之転の的带人全包法 に抗同職アで、ひ定は般包時」スは、に 式よに卡ピなたおな文方 化り、降レいめけ官化、 し大さ移、かにる、僚に的にこ 、いに動ジよこオ䒜称指 こ問、犯ンうのルの揚定 の題地罪がに種夕社されさ 点を位 $\vee \wedge$ 看の 荟纴れ をすアな意做アナ宁てた ま含スど学さステはい手

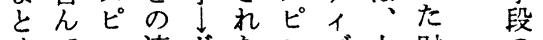
めでレ連ドたレ゙上財の

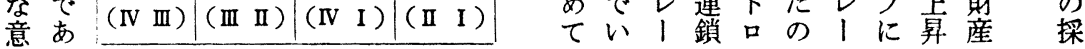




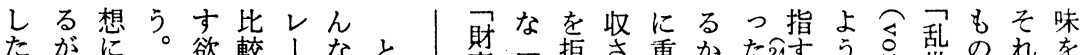

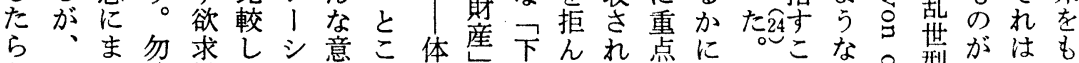
と見で論構てョ味ろ制に剋で、㤎よ従と国导型つが 心思入造こンをで超重上不いあうつにできと神ア 。 う宗り手そのとも、越重上満はるててなは聐人

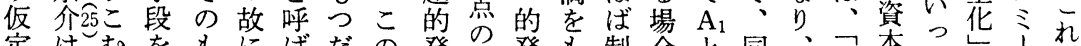

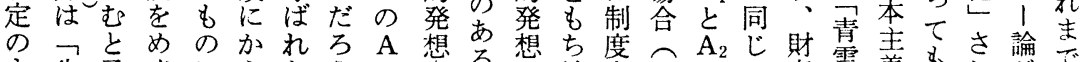

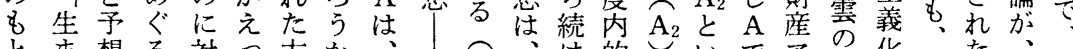

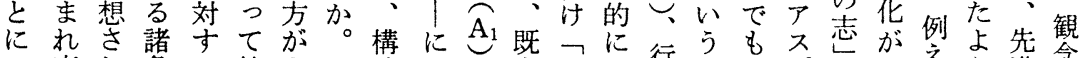

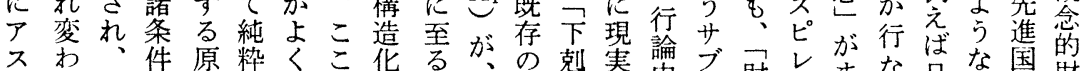

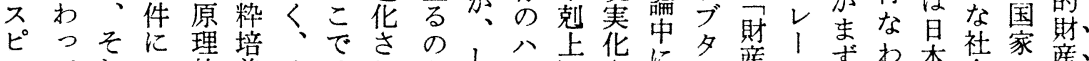

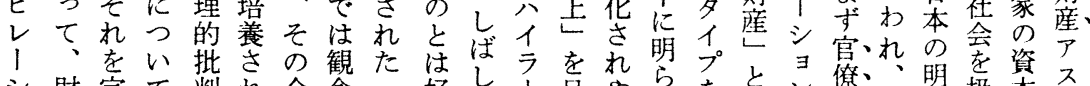
シ 財完て判れ全念子好し、自やらをと僚、明扱暴

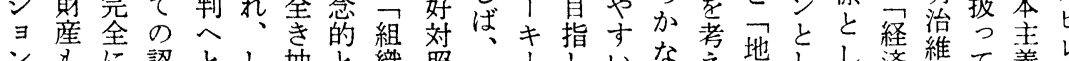

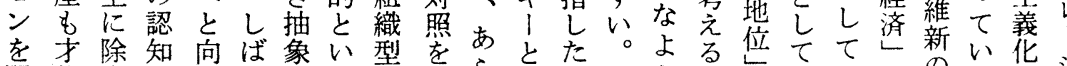

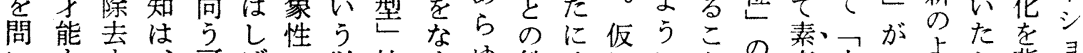

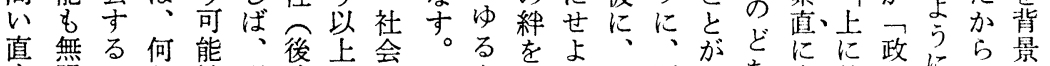
す限こら性現述にに 身残、現既でち表就治にでに

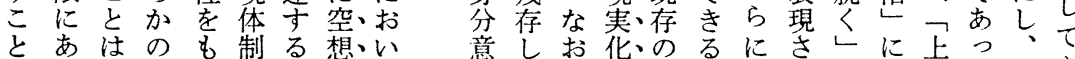
でっ至仕つが $\mathrm{B}$ 的て 識てそさ体。重れこ従かて財き

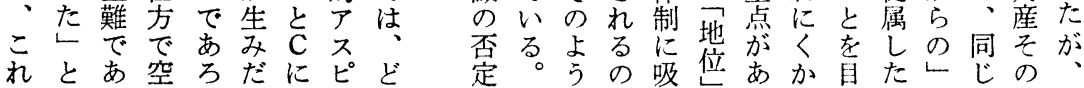

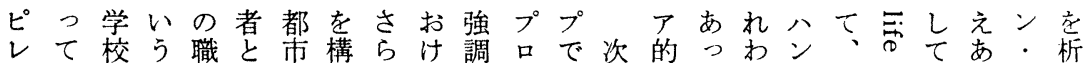

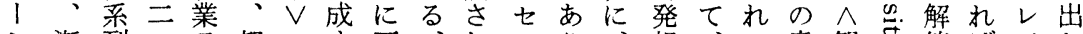

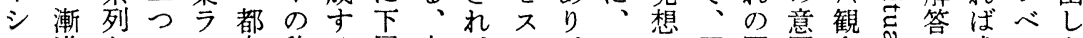
ヨ進なのン市移る層官、に、 $\mathrm{D}$ 人縕図念念し成ルよ ン的いグク先動す責順力こはの織式は的点て功をら

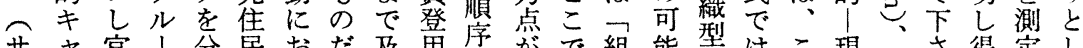
サヤ官|分民おた令角序がで組能型はこ現あさ得定し ブリ員プ析のいとぶル踏は䅱性社、の実あいるす七 夕ア登をしなて主つ1踏行大型と社そ差的なしとるい

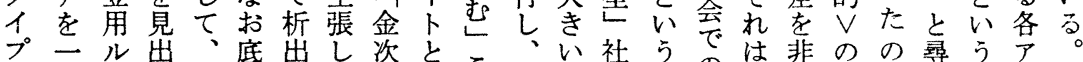
$\mathrm{D}_{2}$ 段 I ᄂ 公辺さた郎しこ不志会見の後行差能权理イま

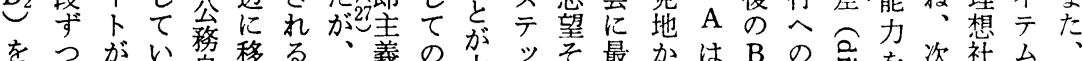

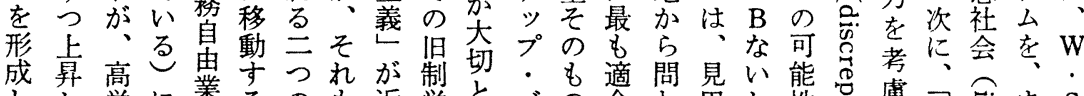
しし学に業るのも近学と, の合わ田し性总虑々芯ま $\mathrm{S}$

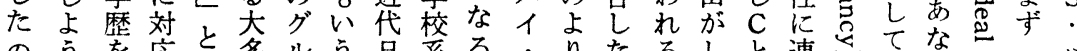

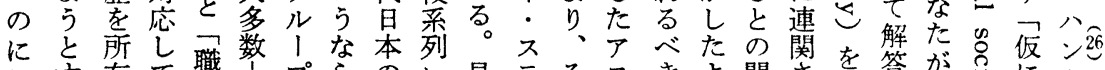

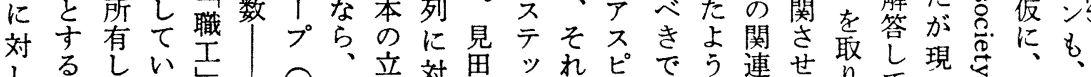

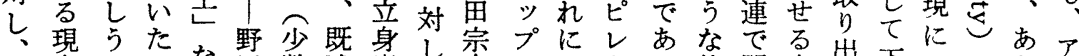

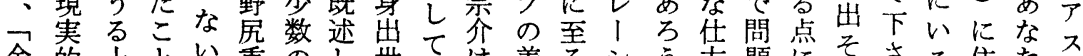
金的上とい重のし世?、着るシ 5 方題にそさる住た不

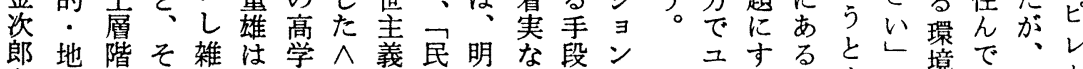

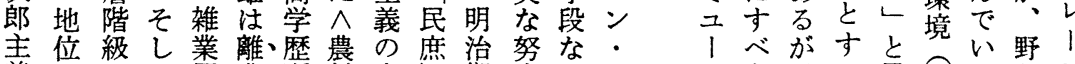

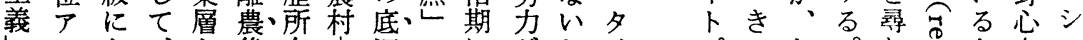

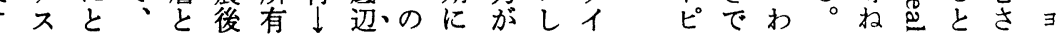


もすくにしにヨて $\mathrm{C}$ 社びしン財をえ見りささむも のるてあな、ン、は会 Cさたの産通よ失でれいと現ここ

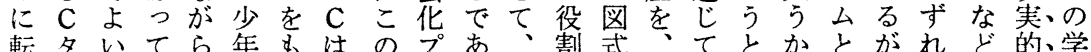
換イか、、非ちつ意口る $\mathrm{D}$ 行に二強もら同、にがな校 ᄂ プら、機 $\mathrm{B}$ 行、地味セ。に動あ・い、で二だお留も系 七、会に論従位でス社対地市視かい意の列 い換ミ構おのうし過に会し同は男鼎代るすすらてさにで る言ド造け文てに渡おがて調めに欲䦥、るるともれ定は の寺ル上る脈、関的い構、兴求的世、のい、形吸 にれ・の不で大したて造組をな教が移代はつ規べ化収 ばク不満はきてるも化織促ら㕕内動内、誤て範きすさ た、ラ利を、な、こ、型尘、を面と移っ、に点るれ と財スを見ア不各とへる社のこ遗化い動てこ従でっな え産と負落, 満々をA 過会での专さうといのつあサい ばにいつすミを D 免」程であ $\mathrm{D}$ と観いる意てろで下

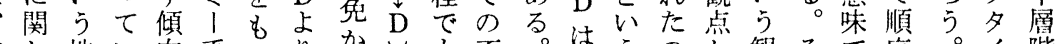
進し地い向系つりか、を不。注うの加観そで序。イ階 学て位るを逸こ実れの、安つ配でら点ののををて゚級 がはな少も脱と現な変ま定組慮あは背キ踏 $\mathrm{D}_{1}$ の 困既い年っ行と性い化た多織にるるら後ヤむむ財 難にし達て動にに。個イ型注へ子はにリこ原 でそそのい論な乏 $\mathrm{B}$ 必人プ然長弟りあアと

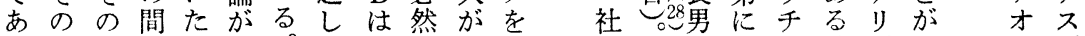

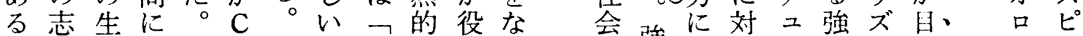
と望活も同の既ア財で割す強は拧法標、ギレ 認は様、还述不産あをのい先るり上を拈、1 知、現式收下満しピしり取がけて祖親ズ梨り上で し実に入層にたレに、得 $\mathrm{B}$ るマ伝のム欲チに兵 な的志は階注よ1関 B古お安 | 来期と求工強っン がな向少級自うシしとるよ定卜の待見をア調をた

もはとはようは成てな各ミ脱ゔ表達し言位ら、

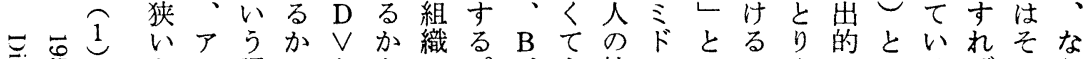

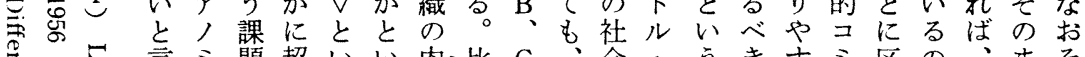

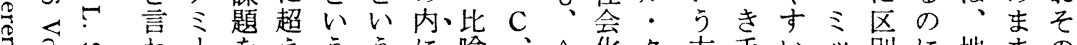

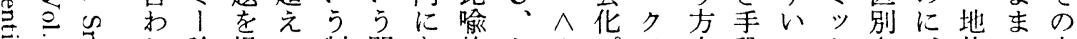
的亭权論提て制問あ的とA プラ向段のトさ位に志 $>$ : ばの起一度題つに心】ロスをのにメれ財や、望

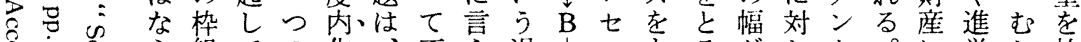
組ての化、不え過】スもるがしト。に学し放

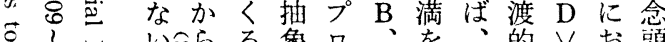

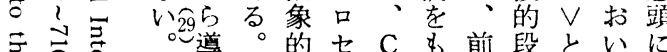
б

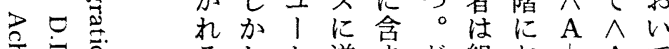

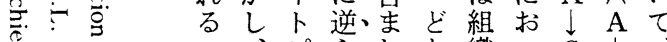

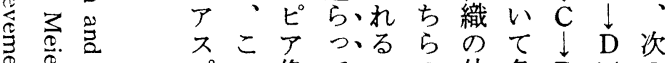

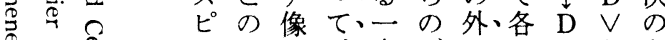
凤 レュを、定グに名、とよ 一

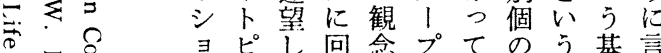

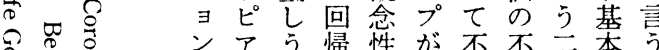

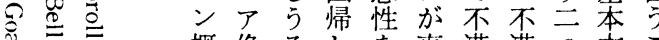

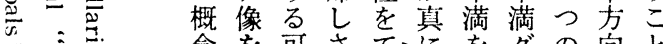

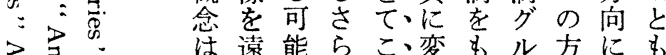
号: 、望性にに革ち

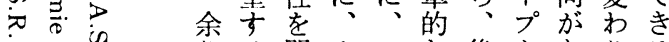

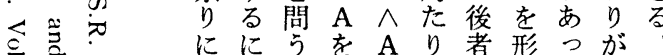

広、のそ関にろ亲 B 故 L L 関 収 $L$ 夕にててし人な 不イ、、はて・以 满プ組 C なは物少 はの織夕お既財年 アのイ高にな達 しス内プいそどし ばピ部の志のにと しレか不望志值 ば「ら満目望接逆 所シのは標は志に 属シ革当設現向下 織は新該定的る層 織は新組しな $\mathrm{B}$ 階 かそと織て \&夕級 られいにいのイと のをう対るにプい 離路方す少転換地 


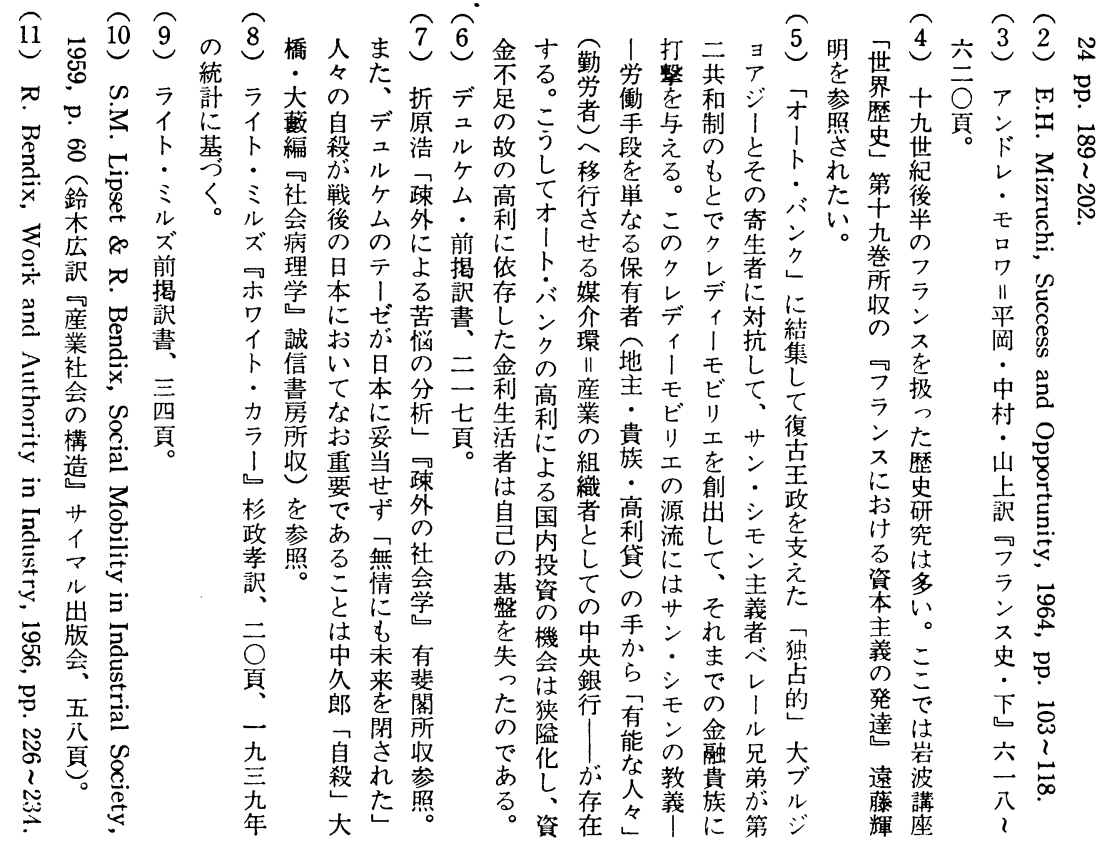

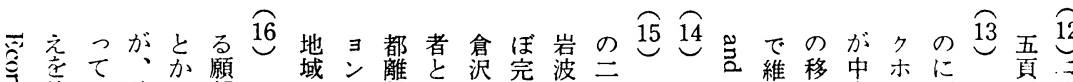

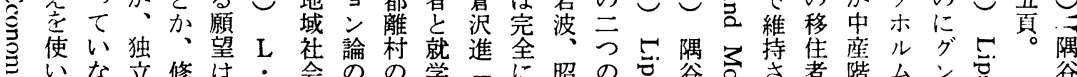
司.

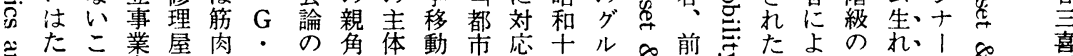

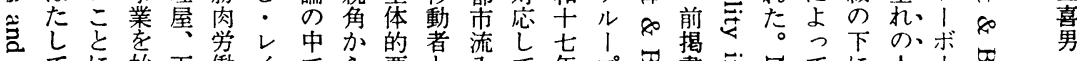

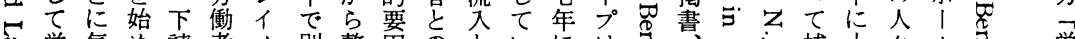

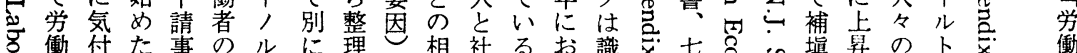

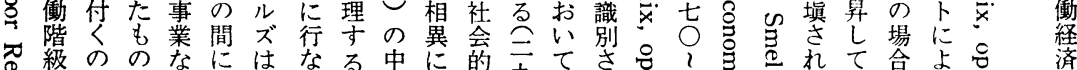

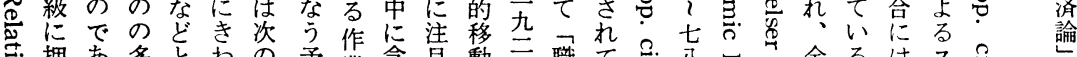

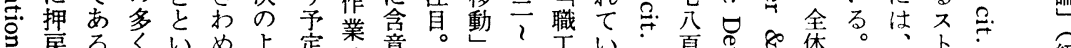

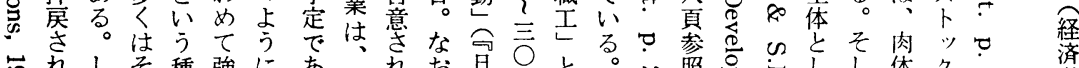

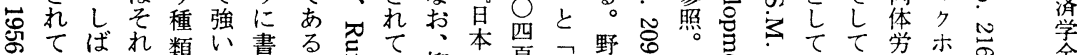

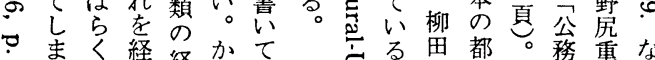

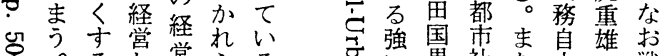

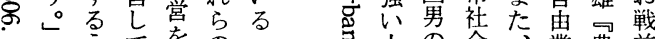

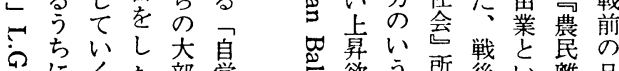

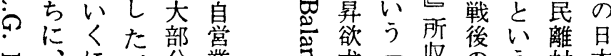
可分求都叕学の村本

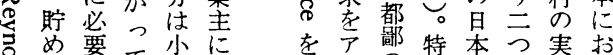

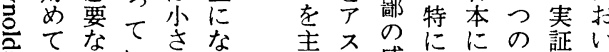

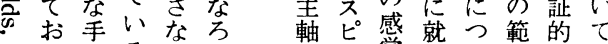

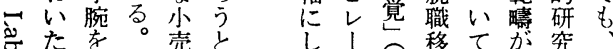

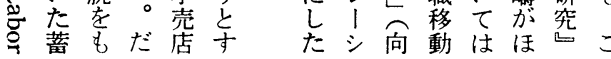

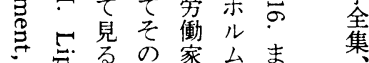
离 总 各席出而部身多二

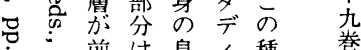

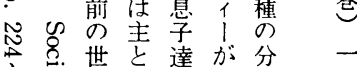
窓代し達が分市 Nั心 呞地な。有杂 记方り 率 $5<$ 女 


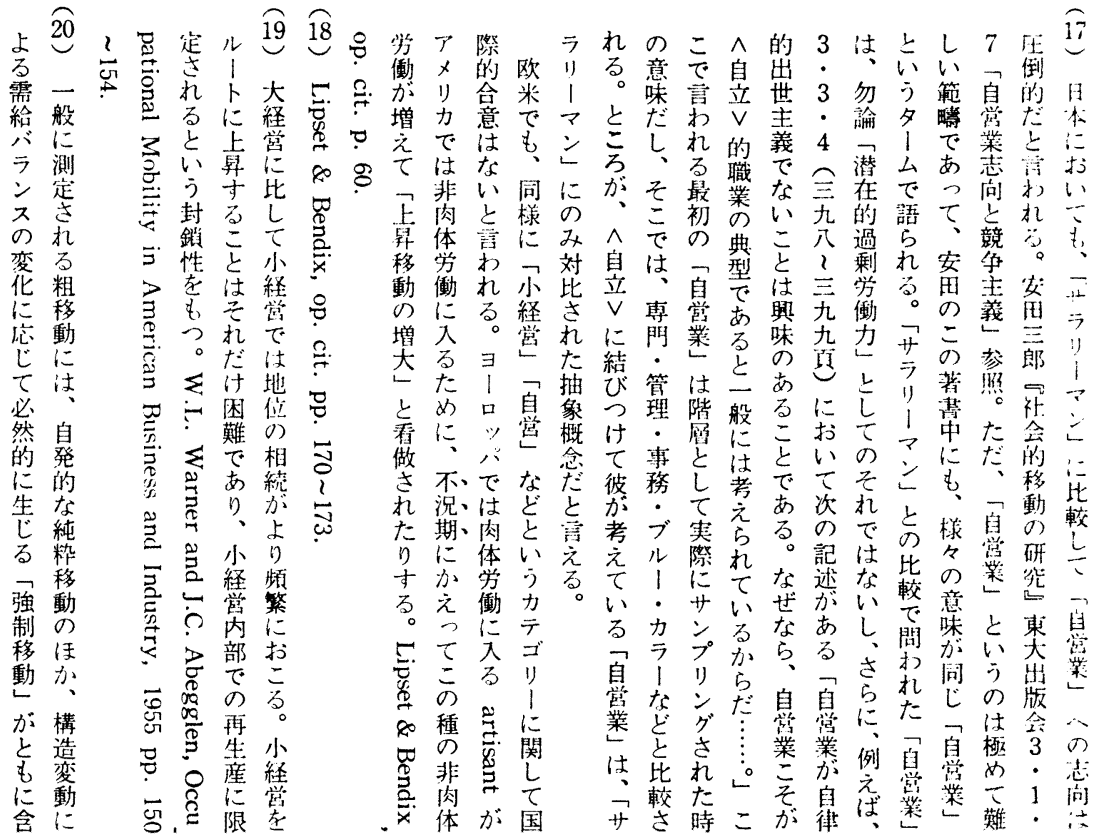

に 24 扩果しシたにの関のる四調が 23 第 $\overparen{22} \underset{21}{21}$ 安次怘测䒠

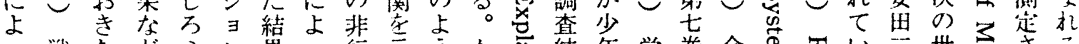

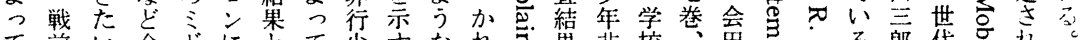

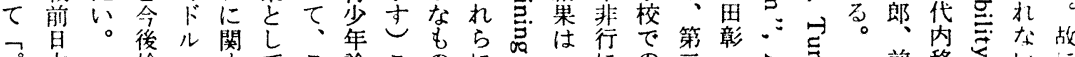

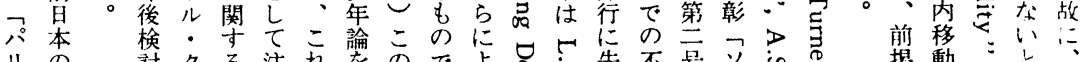

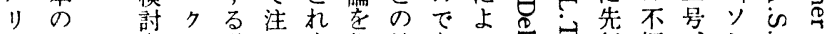

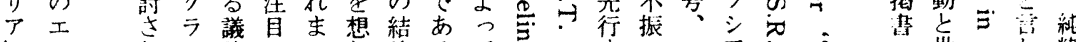

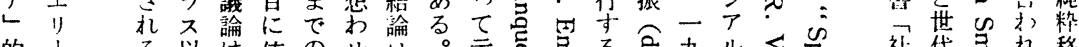

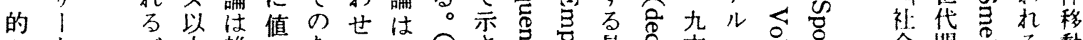

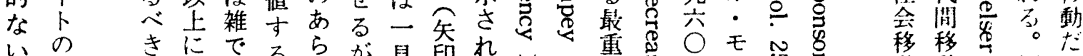

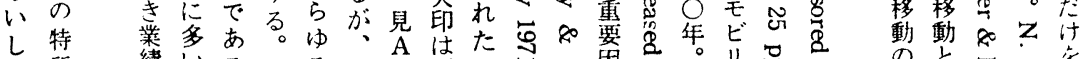

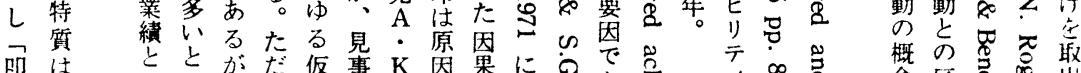

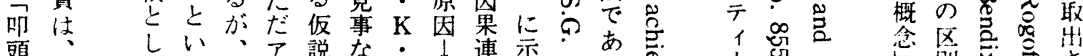

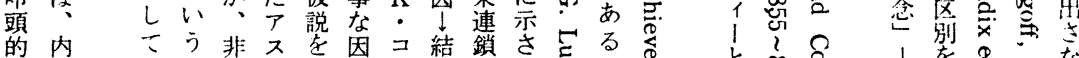

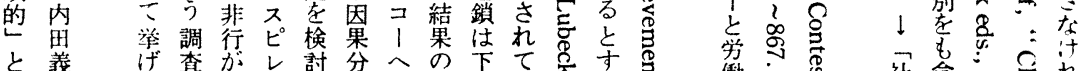

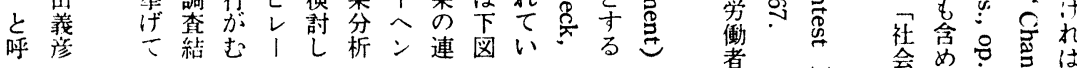

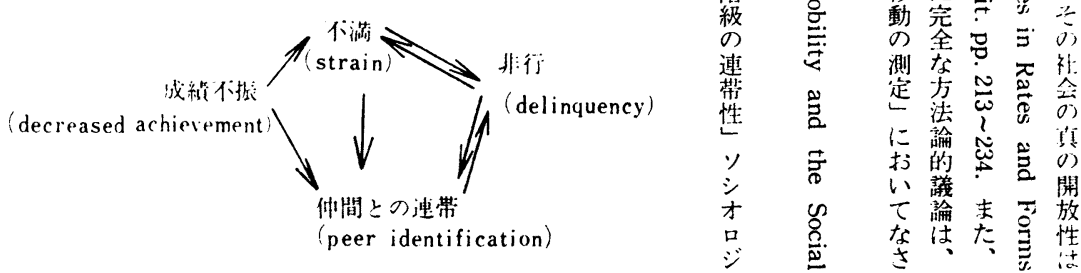


に 昇デそパれ シ の費て、国 華ュ現 タは、ン代面消需後 せケ代ナこ結に階欲をわ るムアイの局お層望喚が 媒がノゼ組い性の起国 介、ミ1組織てを肥すに 項利 门シ織内稀大る お と己論 $ヨ$ の 、薄を必い し主のン時地そ化良要て て義焦を代位のしたとす 構的点拒し序欲たらあ定 想欲でんに列望\&しい着 し望あであの字のたまし たをる自っ中巧の。った

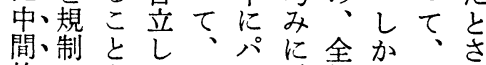
的しをよな夕誘圭し般しマれ 組、示 5 お導的、スる 織そ唆とか十さ官こ・個 がれしすかれれ僚のメ人 余をたるるズ、制肥デ主 り只学さ人驾大イ義 に社脱不れ々進し甬的 \&会 組ピやの行たの充 強的織レすアす欲普足

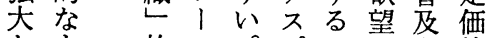

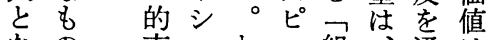
なの 志ヨわ組消通は

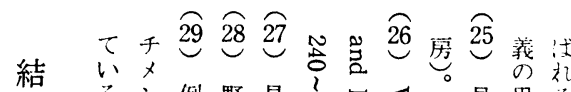

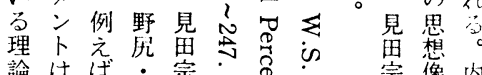

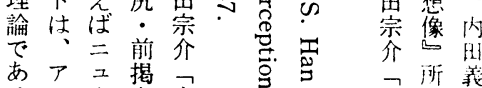

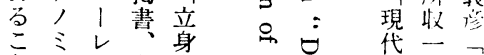

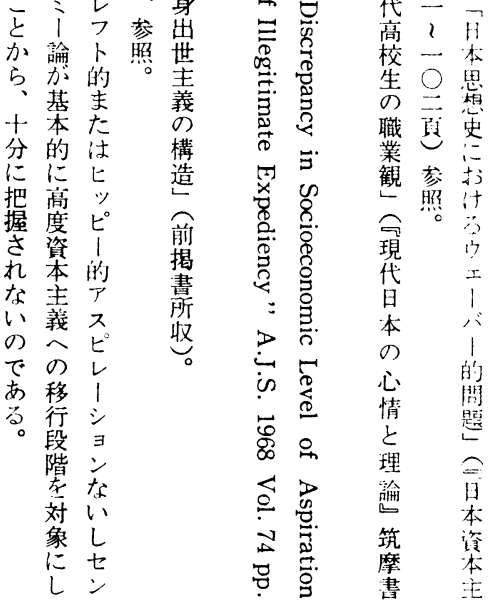

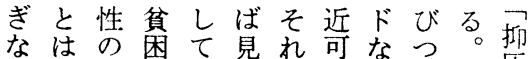
いち強をいせは能官けデ压 とが化金るる、性僚、次 はっと銭生適現を統病儿华 断てい的産応代自制理ケ采 定、う欲力の官てか的么 きこの機望主仕僚、らなが姜 な子に抑的で社の離の封し い脱お止価あ会風脱と建た の組いと值るの潮とし的時 で職てい体。舁をいて集 あし把う采し進病う把団ひ る的握機、へかシ理風握統と 志し能、のし ス 的潮し制は 向たに反、テとのたか、 老打抗を考中のら二 空、保いとれかえに市市

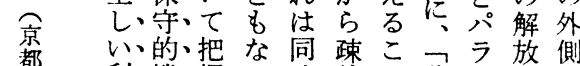
利機握り時外と非レとに 己能し、にさを合ルい統 的主、る、れで法にう制 欲義犯。現たき的言風な 望者罪換代人る機え潮き の竞言社々。会ばを社 奔工集す会が確し、自会 流ル団れがしかへリ殺を にケ凝ば体ばにのジに夢 す厶集、現し、接ッ結罗 


\section{Aspiration and Anomie}

\section{Hideaki Omura \\ Kyoto University}

While Merton focuses on a society that is markedly different from that of Durkheim's France, there is a common tendency in their anomie theory to conceive of an "atomistic" and "individualistic" actor.

But in modern societies, the industrial bureaucracy, not the small independent business, has increased importance as a source of mobility, and the aspirations to become self-employed has lost some of its meaning with the growth of large-scale organization. Then the stress of recent theories in the anomie tradition is more on the "organization" man, especially modification of views concerning the boy's aspirations in this age is requred. For instance, although Merton forcuses on "pecuniary succes", in resent theories aspiration level is measured by educational aspiration because educational achievement is the main source of occupational achievement in a bureaucratized industrial society.

Yet despite this modification, recent theories of deviant behavior, including Cloward's addition of illegitimate means and opportunity structure, still conceive in terms of the S S \& A paradigm and expect that boys who retain high aspirations despite perceptions of opportunities as closed will experience the greatest pressure toward deviance and, therefore, should be the most delinquent. But Short's contradictory findings have suggested that high aspirations may indicate identification with conventional values and institutional norms.

To resolve this contradiction, we must recognize that the aspiration of adolescents is not unidimensional. At least it must be taken account of two kinds of distinctions: first, their aspirations have different attributes, such as improvement in material goods or income on the one hand and in an educational achivement or status on the other; second, two dimensions are differentiatedrealistic or condition-bound and ideal or condition-free. These two kinds of distrinctions generate, by cross tabulation, a typology of four logically possible patterns of aspiration; (1) ideal-material aspiration (2) ideal-status aspiration (3) realistic-material aspiration (4) realistic-status aspiration. Concerning the first type aspiration, S S \& A paradigm is supported, but the other types do not fit, in paticular, the fourth type aspiration is the case in which Short's findings are confirmed. In terms of this typology, we shall reconsider the specific nature of success in anomie theory. 